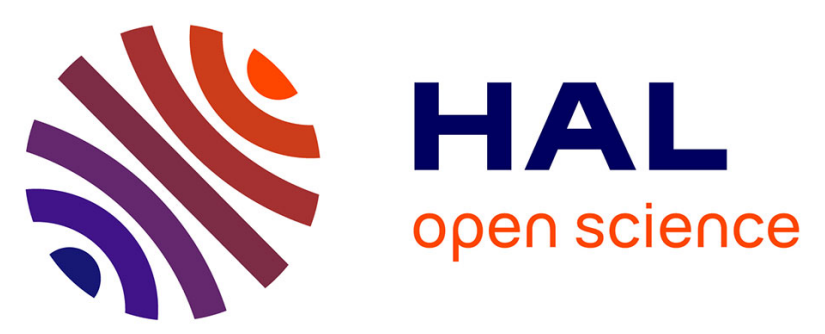

\title{
Integration of a thermochemical energy storage system in a Rankine cycle driven by concentrating solar power: Energy and exergy analyses
}

\author{
Ugo Pelay, Lingai Luo, Yilin Fan, Driss Stitou, Cathy Castelain
}

\section{- To cite this version:}

Ugo Pelay, Lingai Luo, Yilin Fan, Driss Stitou, Cathy Castelain. Integration of a thermochemical energy storage system in a Rankine cycle driven by concentrating solar power: Energy and exergy analyses. Energy, 2019, 167, pp.498-510. 10.1016/j.energy.2018.10.163 . hal-02364774

\section{HAL Id: hal-02364774 \\ https://hal.science/hal-02364774}

Submitted on 27 Nov 2020

HAL is a multi-disciplinary open access archive for the deposit and dissemination of scientific research documents, whether they are published or not. The documents may come from teaching and research institutions in France or abroad, or from public or private research centers.
L'archive ouverte pluridisciplinaire HAL, est destinée au dépôt et à la diffusion de documents scientifiques de niveau recherche, publiés ou non, émanant des établissements d'enseignement et de recherche français ou étrangers, des laboratoires publics ou privés. 


\title{
Integration of a Thermochemical Energy Storage System in a Rankine Cycle Driven by Concentrating Solar Power: Energy and Exergy Analyses
}

\author{
Ugo PELAYa, Lingai LUOa,*, Yilin FANa, Driss STITOUb, Cathy CASTELAINa \\ ${ }^{a}$ Laboratoire de Thermique et Energie de Nantes (LTEN), CNRS UMR 6607, Université de Nantes, \\ La Chantrerie, Rue Christian Pauc, BP 50609, 44306 Nantes Cedex 03, France \\ ${ }^{b}$ Laboratoire PROcédés, Matériaux et Energie Solaire (PROMES), CNRS UPR 8521, Tecnosud, \\ Rambla de la thermodynamique, 66100 Perpignan, France
}

\begin{abstract}
:
This paper proposes and investigates novel concepts on the integration of a thermochemical energy storage (TCS) system in a concentrating solar power (CSP) plant. The TCS material used is calcium oxide reacting with water and the power cycle studied is a Rankine cycle driven by CSP. Firstly, three integration concepts on the coupling of the TCS system with the Rankine cycle are proposed, including the thermal integration concept, the mass integration concept and the double turbine concept. Then, an energy analysis is performed to determine and compare the theoretical overall energy efficiency of the proposed concepts. After that, an exergy analysis is also carried out for the selected integration concepts so as to evaluate and compare the overall exergy efficiency of the installation with TCS integration.
\end{abstract}

The results show that the turbine integration concept has the highest overall energy efficiency (0.392), followed by the thermal integration concept (0.358) and the mass integration concept (0.349) under ideal conditions with $11 \mathrm{~h}$ of charging and $13 \mathrm{~h}$ of discharging. The energy storage density using calcium hydroxide as the storage media is estimated to be about $100 \mathrm{kWh}_{\mathrm{el}} \cdot \mathrm{t}^{-}$ 1. Exergy analysis results also indicate that the turbine integration concept seems to be the best option under the tested conditions.

Keywords: Thermal energy storage (TES); Thermochemical; Rankine cycle; Concentrating solar power (CSP); Integration concept; Calcium hydroxide; exergy analysis

\section{Declarations of interest: none}

\footnotetext{
*Corresponding author. Tel.: +33 240683167; E-mail address: lingai.luo@univ-nantes.fr
} 


\section{Introduction}

The increasing energy demand, the environmental protection issue and the national energy independence all over the world call for researches aiming at more efficient use of renewable energy such as solar energy. Among various solar energy technologies, the Concentrating Solar Power (CSP) plants are expected to play an important role in the energetic scenarios owing to its advantages in terms of high efficiency, low operating cost and good scale-up potential [Cáceres 2013; Zhang 2013; Dunham 2014; Balghouthi 2016]. According to IRENA [2016], the CSP deployment would reach $44 \mathrm{GW}$ in the reference scenario (Remap 2030). It is estimated that the CSP would contribute up to $11.3 \%$ of the electricity production in the year 2050 , with $954 \mathrm{GW}$ of installed capacity [IEA 2014; del Río 2018].

One of the advantages of CSP technology is the possibility of integrating a thermal energy storage (TES) function, permitting the production of electricity any time when it is the most needed and valuable, whether during the peak hours, nights, or cloudy intervals [Zhang 2016; Dowling 2017; Alva 2018]. To do this, a TES system at high temperature should be designed and installed properly between the solar field and a power cycle. Although adding a TES system usually increases the investment cost of the CSP plant, it improves significantly its adaptability and dispatchability. CSP plants (existing or under construction) having TES systems at high temperature are summarized in recent reviews [e.g., Tian 2013; Kuravi 2013; Pelay 2017a; b]. The storage capacity in terms of discharging time is generally between 3 to 8 hours, and recently up to 15 hours (Gemasolar, Spain) aiming at round-the-clock electricity production driven by solar energy [Dunn 2012].

The most commonly used storage technology is based on the sensible heat storage, in which the thermal energy is stored/released by raising/decreasing the temperature of a storage material. This technology is the most mature and deeply investigated, with a wide variety of both liquid (e.g., pressurized water, molten salt, mineral oil, etc.) and solid (e.g., sand, rock, cast iron, etc.) materials being used for CSP applications [Gil 2010; Tiskatine 2017]. Some recent developments are also reported, such as on the use of industrial wastes or by-products [Ortega-Fernández 2015; Gutierrez 2016], chloride salts [Myers 2016], lithium coupled with molten salts [Cabeza 2015], or solid particles [Zhang 2017a; Calderón 2018]. However, their limited energy density (usually between 60 $\mathrm{kWh}_{\mathrm{th}} \cdot \mathrm{m}^{-3}\left(200{ }^{\circ} \mathrm{C}-300{ }^{\circ} \mathrm{C}\right)$ for sand, rock and mineral oil, and $150 \mathrm{kWh}_{\mathrm{th}} \cdot \mathrm{m}^{-3}$ for cast iron $\left(200{ }^{\circ} \mathrm{C}\right.$ $400{ }^{\circ} \mathrm{C}$ ) [Fernandes 2012]) increases significantly the size of TES systems. Latent heat storage materials such as Phase Change Materials (PCMs) are also proposed for CSP applications owing to their higher storage capacity [Gil 2010; Pitié 2013; Sharma 2015; Zhang 2017b; Chirino 2018]. But their small thermal conductivity (commonly $0.2-0.8 \mathrm{~W} \cdot \mathrm{m}^{-1} \cdot \mathrm{K}^{-1}$ ) usually limits the heat transfer, resulting in very slow charging and discharging processes [Nithyanandam 2015]. Some new advances on the effective encapsulation of PCMs [Zhang 2014; Parrado 2015] as well as the enhancement of thermal conductivity are summarized in recent papers [Xu 2015; Liu 2016; Alva 2018]. 
Besides the sensible and latent heat storage technologies, the thermochemical storage (TCS) is a promising solution for its highest storage capacity (up to 10 times greater than latent storage [Pardo 2014a]), wide accessible temperature range and long storage duration at ambient temperature [Prieto 2016]. This technology is mainly based on reversible chemical reactions (e.g., gas-solid) involving absorbing or releasing a large amount of reaction heat:

$$
\{S, n G\}+\text { Heat } \leftrightarrow\{S\}+n\{G\}
$$

The charging stage uses solar energy for the decomposition of $\{S, n G\}$ associated with the condensation of the gas while the discharging stage brings the solid and gas into contact for heat release by the exothermic reaction. TCS material candidates at a medium or high temperature (300$1000{ }^{\circ} \mathrm{C}$ ) for CSP application include metallic hydrides, carbonates system, hydroxides system, redox system, ammonia system and organic system [Kuravi 2013]. Their mains characteristics, advantages/disadvantages and experimental feedback are reviewed and summarized in [Pelay 2017a].

Beyond the testing of new TCS materials [e.g., Deutsch 2017; Valverde 2017; Bagherisereshki 2018] and proper reactor designs [e.g., Álvarez De Miguel 2013; Schmidt 2017; Wokon 2017; Pan 2017] and pilot scale testing [Tescari 2017a; b], the TCS system must be coupled in a proper way with the vapor generator of the power cycle (e.g., Rankine cycle) in a CSP plant. However, relatively little attention seems to be given to this integration issue. Recently, Cabeza et al. [2017] proposed a new concept of consecutive TCS reactions (either one cycle or two coupled cycles) and its implementation in CSP plants, with the purpose of eliminating reversibility problems and therefore improving the overall efficiency. Ortiz et al. [2017] proposed possible integration schemes of calcium looping $\left(\mathrm{CaO}-\mathrm{CaCO}_{3}\right)$ for power production by direct or indirect means. Their results showed highest plant efficiencies up to $45-46 \%$ using a closed carbon dioxide Brayton power cycle. Noteworthy is the very recent work of Schmidt and Linder [2017], in which an integration option of the TCS system into a CSP plant has been proposed and analyzed. Their analysis showed that a storage efficiency up to $87 \%$ might be reached when the required steam production during discharge is thermally integrated into the Rankine steam cycle.

From the above literature survey, one may find that the research on how to integrate the TCS system to the power cycle of the CSP plant is insufficient. Actually, it is an essential issue for the implementation and application of TCS technology, calling for deeper and extensive investigations. The main objectives and originalities of this paper are therefore threefold: (1) to propose various novel integration concepts of TCS system into the Rankine cycle driven by CSP, for both charging and discharging stages; (2) to perform a detailed energy analysis of the proposed integrated concepts and to evaluate impacts of various influencing factors on the overall energy efficiency of the CSP plant; and (3) to discuss and compare the second law efficiency of the proposed integration concepts through an exergy analysis.

This paper is organized as follows. In section 2, the selected gas-solid reaction and material are briefly introduced and the key issue on how to manage the water vapor from the TCS reactor is 
identified. Three novel TCS integration concepts (thermal integration, mass integration and turbine integration) are proposed and described in section 3 . The performance modelling of the three integration concepts based on energy analysis is presented and discussed in section 4 . Section 5 provides an exergy analysis of the integration concepts. Finally, main conclusions and future work are summarized in section 6 .

\section{Thermochemical reaction and its operation}

In this section, we briefly introduce the selected gas-solid reaction and materials, as well as the identified key issues for the integration of TCS unit into the Rankine cycle.

\subsection{Reaction used as TCS storage media}

Various hydrates and hydroxides have been proposed as potential TCS materials, as summarized in some latest papers [e.g., Aydin 2015; André 2016; Liu 2016; Prieto 2016; Pelay 2017 a; Zhang 2016]. Among them, the $\mathrm{CaO} / \mathrm{H}_{2} \mathrm{O}$ couple has been deeply studied with a great amount of experimental feedback [e.g., Azpiazu 2003; Michel 2012; Schaube 2013a; b; Pardo 2014b; Yan 2016; 2017; Sakellariou 2017]. It is found to be a pertinent candidate as TCS material for CSP application with various features, including for high-temperature use $\left(450 \sim 600{ }^{\circ} \mathrm{C}\right)$, good reversibility, operating pressure close to the atmospheric pressure, low material cost, environment-friendly and high energy density (about $3 \mathrm{GJ} \cdot \mathrm{m}^{-3}$ ), etc. As a result, it is selected a priori for this conceptual study. The reaction formula is shown in Eq. (2).

$$
\mathrm{Ca}(\mathrm{OH})_{2(s)}+\Delta h_{R} \leftrightarrow \mathrm{CaO}_{(s)}+\mathrm{H}_{2} \mathrm{O}_{(. g)}
$$

For a reaction temperature at $500{ }^{\circ} \mathrm{C}$, the equilibrium pressure equals to $0.1 \mathrm{MPa}(1 \mathrm{bar})$. Under this condition, the reaction heat $\left(\Delta h_{R}\right)$ is found to be $104 \mathrm{~kJ} \cdot \mathrm{mol}(\mathrm{CaO})^{-1}=5774.56 \mathrm{~kJ} \cdot \mathrm{Kg}\left(\mathrm{H}_{2} \mathrm{O}\right)$ 1 [Schaube, 2011].

\subsection{Management of the water vapor from the TCS reactor}

The integration of TCS reactor in a solar power plant is a so-called passive concept in which the storage medium $(\mathrm{CaO})$ is kept motionless and heated-up or cooled-down by the circulation of a heat transfer fluid (HTF) [Pelay 2017a]. When used as TCS material in a CSP plant, water vapor at high temperature produced by the decomposition during the charging stage should preferably be condensed to saturated liquid and stored in a separate reservoir at ambient pressure (0.1 MPa). Hence the required volume for the storage unit is greatly reduced. Meanwhile, the superheated steam $\left(500^{\circ} \mathrm{C}\right)$ contains a significant amount of thermal energy, a part of which is possible to be recovered so as to increase the overall efficiency of the whole system, as shown in Fig. la. Instead of condensing the water vapor directly at the outlet of the TCS reactor by an additional condenser, alternative energy valorization options are actually available, either to produce extra electricity through an additional turbine or to preheat the steam of the Rankine cycle. 
During the discharging stage, the exothermic synthesis happens when $\mathrm{CaO}$ and water vapor are in contact. Supposing that the CSP plant is driven only by solar energy, it is necessary to find a heat source to vaporize water stored previously in the liquid form through an evaporator, as shown in Fig. 1b. This heat source should have a higher temperature than that of liquid water to be evaporated (e.g., $100^{\circ} \mathrm{C}$ at 1 bar).

As a result, the positioning of TCS reactor in the whole system and the way of managing water vapor are key issues for an energy-efficient integration of TCS unit into the Rankine cycle. Different integration concepts shown in the following section will highlight the options proposed for these key points.

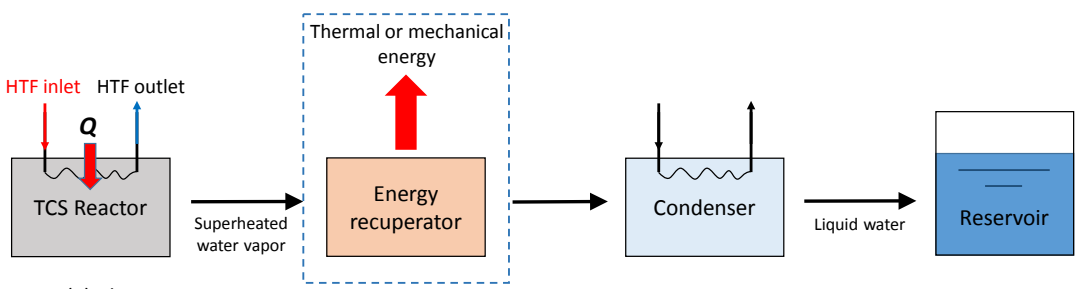

(a) Charging stage

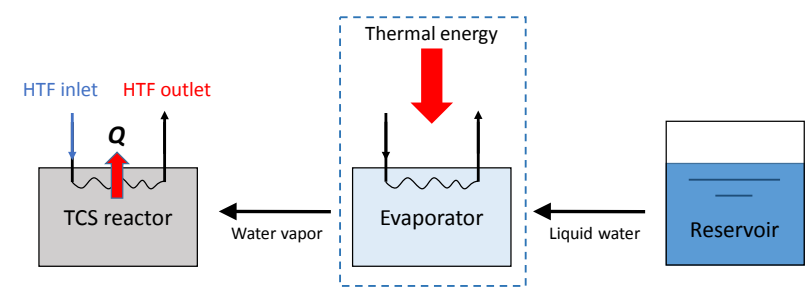

(b) Discharging stage

Figure I. Management of water vapor as a key issue for energy-efficient TCS integrations into the Rankine cycle. (a) charging stage; (b) discharging stage.

\section{TCS integration concepts}

In this section, we shall firstly present a conventional regenerative Rankine cycle driven by CSP without storage as a reference case [Moran, 2003]. Then, three novel integration concepts of TCS unit into the Rankine cycle are proposed and described, named as thermal integration, mass integration and turbine integration.

\subsection{Conventional Rankine cycle without TES}

Figure 2 shows a representative schematic view of the conventional regenerative Rankine cycle driven by CSP. The main components in this cycle include a steam generator, a turbine, a condenser, an open feedwater heater and pumping and piping accessories. Solar energy is firstly absorbed by the solar receiver at the top of solar tower and transferred to the HTF. This amount of thermal energy is then utilized in converting water contained in generator (point 6) into superheated steam at the suitable pressure and temperature (point 1). The superheated steam then flows through 
the turbine. While doing work in the turbine, the pressure of steam is reduced. The steam leaving the turbine (point 2) passes through the condenser and is condensed into liquid at low pressure for recycling. An open (or direct-contact) feedwater heater serves as a mixing chamber where the steam extracted from the turbine (point 2') mixes with the feedwater leaving the pump (point 4). Ideally, the mixture leaves the heater as the saturated liquid at the heater pressure (point 5). This steam regeneration configuration usually enhances the thermal efficiency of the Rankine cycle at the cost of lower electricity production rate due to steam extraction.

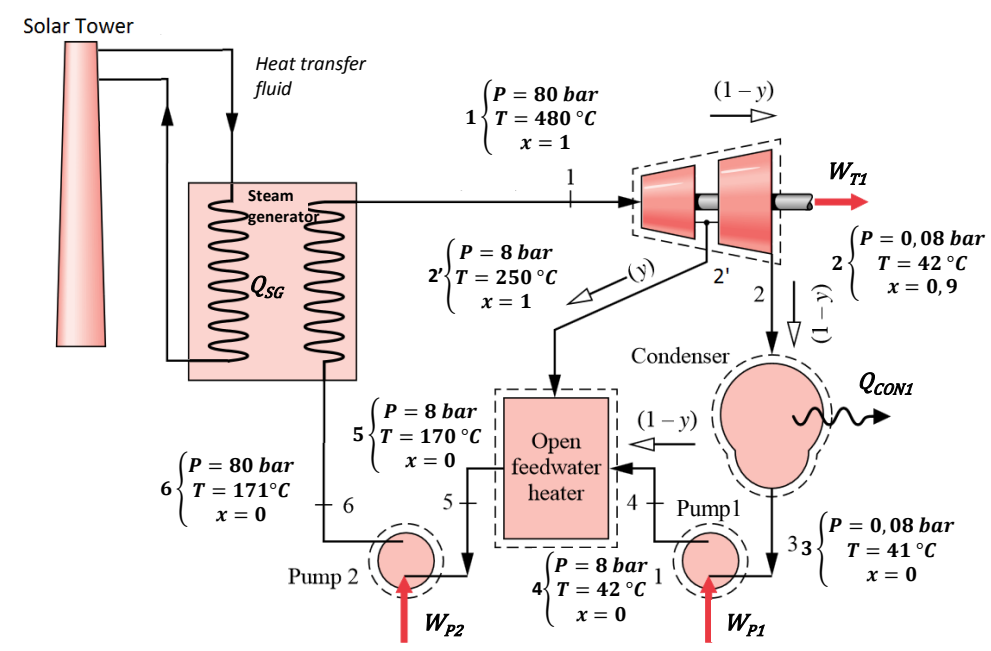

Figure 2. Schematic view of a conventional regenerative Rankine cycle driven by CSP without TES [Moran 2003]

\subsection{Concept 1: Thermal integration (Thermal Int.)}

The Thermal Int. concept is shown in Fig. 3. The added TCS unit comprises of a TCS reactor, a water reservoir, a second condenser and two heat exchangers. There are three fluid circuits in the integrated system: the solar circuit as energy supply, the principal Rankine circuit for power generation and the TCS circuit for energy storage. Note that although the working fluids are identical as pure water or steam, the principal Rankine circuit and the TCS circuit are independent of each other without direct mass contact or exchange. Hence, this concept is named as Thermal Int. because there is only heat exchange between the TCS circuit and the Rankine circuit.

During the charging stage (Fig. 3a), the HTF (e.g., pressurized air or molten salt) from the solar tower offers the steam generator sufficient amount of thermal energy to run the principal Rankine cycle. Meanwhile, it heats the $\mathrm{Ca}(\mathrm{OH})_{2}$ reactive salts in the TCS reactor up to $500{ }^{\circ} \mathrm{C}$ at 1 bar to initiate the decomposition. The water vapor generated in the TCS reactor is partially condensed in the heat exchanger 1 , then completely condensed in the condenser 2 and finally be stored as the saturated liquid $\left(100^{\circ} \mathrm{C}, 1 \mathrm{bar}\right)$ in a separate water reservoir. The sensible and latent heat released by the water vapor will be used to preheat the working fluid of the principal Rankine circuit via heat exchanger 1 . The $\mathrm{CaO}$ reaction product (and subsequent reactant) remains in the TCS reactor. This integration concept permits the steady operation of the principal Rankine circuit for power production and the TES in parallel. 
During the discharging stage (Fig. 3b) when solar energy is not available, the liquid water stored in the reservoir is firstly heated up and vaporized by the high temperature steam extracted from the turbine of the principal Rankine circuit via the heat exchanger 2 . The saturated vapor $\left(100^{\circ} \mathrm{C}, 1\right.$ bar $)$ enters then into the TCS reactor and reacts with the $\mathrm{CaO}$ for the synthesis of $\mathrm{Ca}(\mathrm{OH})_{2}$. The heat released from this exothermic reaction in the TCS reactor runs the principal Rankine cycle steadily under the same operational conditions (temperature, pressure and steam mass flow-rate) as during the charging stage. In this case, the TCS reactor also serves as the steam generator.

The positive aspect of this concept is that it is technically simple to implement whereas the disadvantage is that a separate reservoir is required to store the liquid water resulting from the TCS reaction, implying a higher capital cost.

(a) Charging

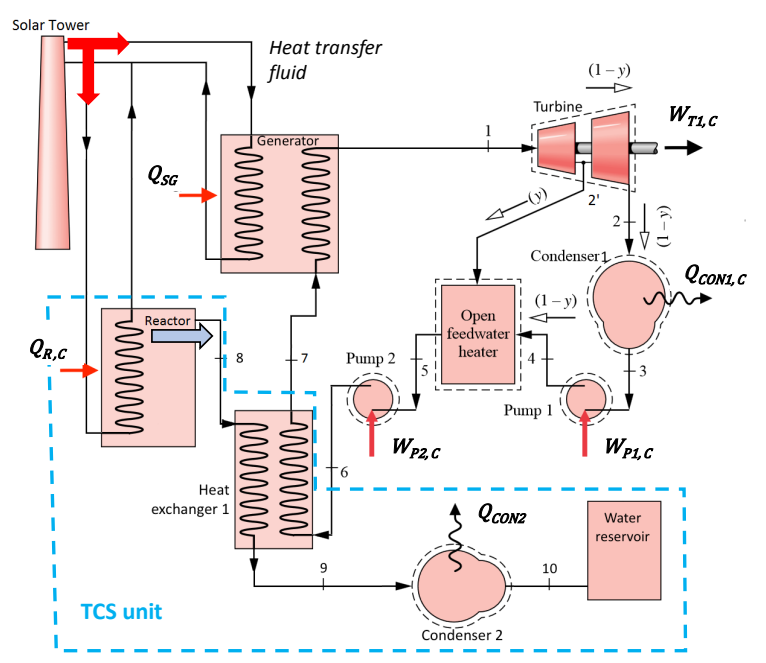

(b) Discharging

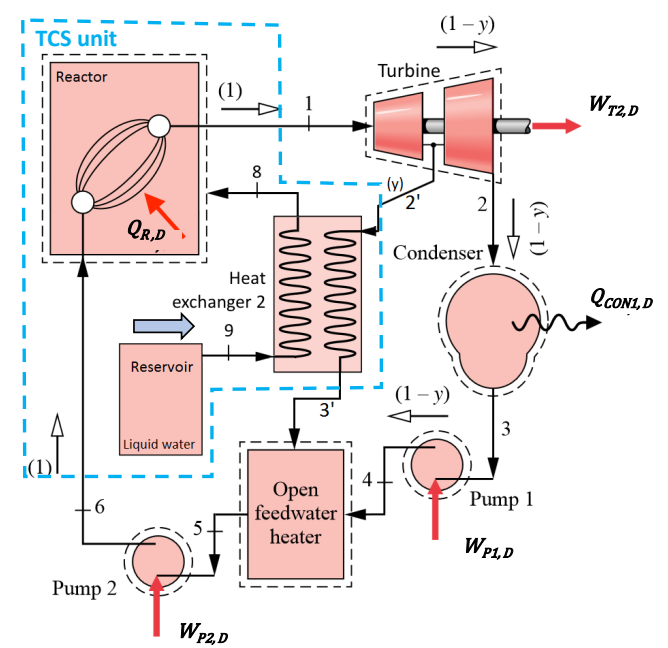

Figure 3. Schematic view of the thermal integration concept. (a) charging stage; (b) discharging stage [Luo 20 I6].

\subsection{Concept 2: Mass integration (Mass Int.)}

The Mass Int. concept is shown in Fig. 4. Compared to the conventional Rankine cycle as shown in Fig. 2, a TCS unit is added including a TCS reactor, a second condenser, a throttle valve, a third pump and two heat exchangers. There are still three fluid circuits in the installation: the solar circuit, the principal Rankine circuit and the TCS circuit. But different from the abovementioned Thermal Int. concept, the principal Rankine circuit and the TCS circuit are coupled and share the same working fluid (pure water or steam) with mass exchange. As a result, this concept is named as Mass Int.

During the charging stage (Fig. 4a), the water vapor generated in the TCS reactor is partially condensed in the heat exchanger 1 , depressurized by the throttle valve, completely condensed in the condenser 2 and finally stored as the saturated water $\left(41{ }^{\circ} \mathrm{C}, 0.008 \mathrm{MPa}\right)$ in the water reservoir shared with the principal Rankine circuit. The sensible and latent heat released by the common 
water vapor will be used to preheat the working fluid of the Rankine cycle via the heat exchanger 1 located upstream of the steam generator.

During the discharging stage (Fig. 4b), the liquid water stored in the reservoir will be pressurized by pump 3 and then evaporated by exchanging heat with the extracted steam via the heat exchanger 2 . The saturated vapor $\left(100^{\circ} \mathrm{C}, 0.1 \mathrm{MPa}\right)$ enters the $\mathrm{TCS}$ reactor and reacts with the $\mathrm{CaO}$ reactive salts stored inside. Again, the TCS reactor serves as the steam generator to run the Rankine cycle steadily under the same operational conditions as during the charging stage.

The Mass Int. concept seems less interesting than the Thermal Int. concept because more components are required for the TCS unit, implying higher capital costs. Moreover, the mixing of working fluids between the principal Rankine circuit and the TCS circuit could bring further technical difficulties because of the massive fines formation. An efficient filtration system (e.g., sintered metal fiber or ceramic filters [Smolders 2000]) may have to be implemented for dust removal to prevent the eventual damage of the turbine. A special design of the TCS reactor coupled with metal filter may also be considered [Schmidt 2017].

(a) Charging

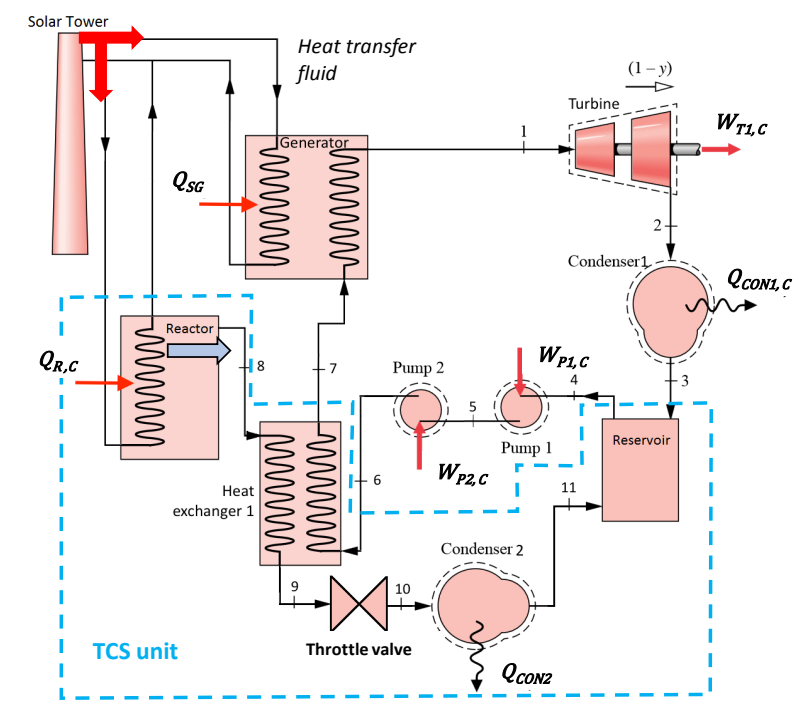

Figure 4. Schematic view of the mass integration concept. (a) charging stage; (b) discharging stage [Luo 20 I6]. (b) Discharging

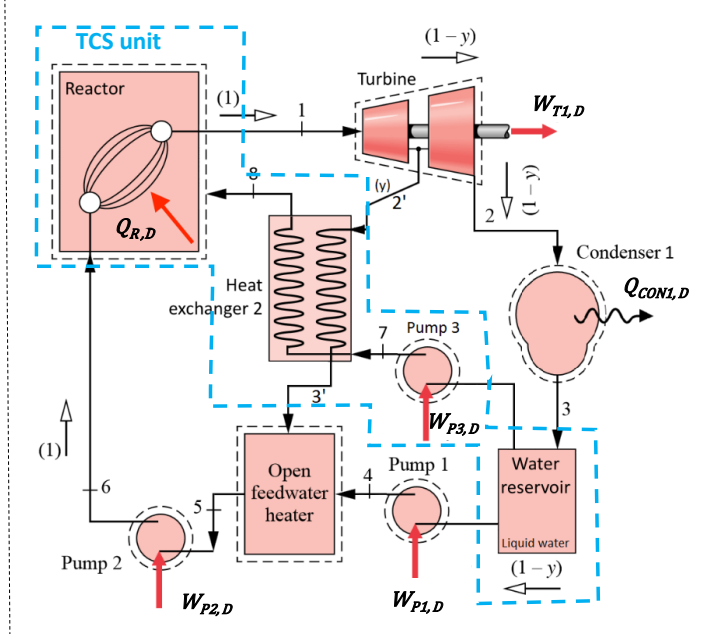

\subsection{Concept 3: Turbine integration (Turbine Int.)}

Figure 5 presents a schematic view of the Turbine Int. concept. Additional components of the TCS unit include a TCS reactor, a second turbine, a second condenser, a third pump, a water reservoir and a heat exchanger. The principal Rankine circuit and the TCS circuit are completely independent of each other during the charging stage (no heat or mass exchange) and thermally coupled during the discharging stage.

During the charging stage (Fig. 5a), the water vapor generated in the TCS reactor passes through the turbine 2 , condensed in the condenser 2 and finally stored as the sub-saturated water 
$\left(41.5^{\circ} \mathrm{C}, 0.1 \mathrm{MPa}\right)$ in a water reservoir. A part of its thermal energy is valorized as power production via the second turbine. The integration concept for the discharging stage (Fig. 5b) is the same as that of Thermal Int. concept, in which water stored in the reservoir will be evaporated by exchanging heat with the extracted steam via the heat exchanger 2.

The main feature of this concept is the additional power production in parallel of the one provided by the principal Rankine circuit during the charging stage. However, the implementation of this second turbine, which is partially used only during the charging stage, implies higher capital cost for the CSP plant.

(a) Charging

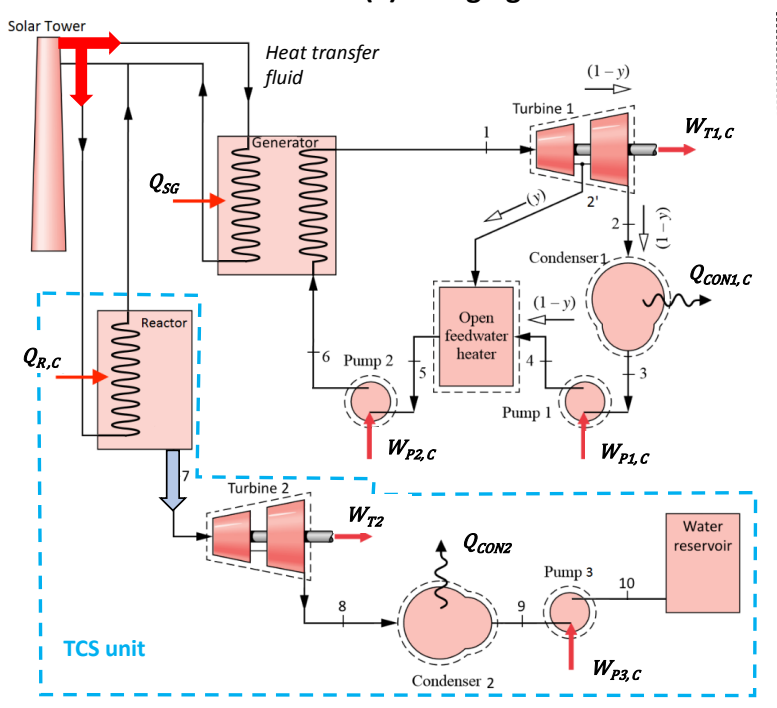

(b) Discharging

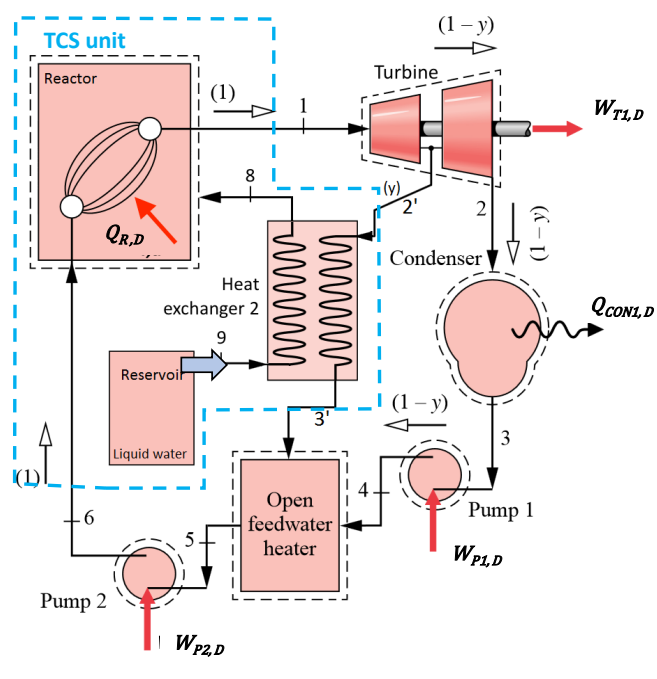

Figure 5. Schematic view of the turbine integration concept. (a) charging stage; (b) discharging stage [Luo 2016].

\section{Energy analysis of different TCS integration concepts}

This section presents a detailed energy analysis of three proposed concepts of TCS integration into the Rankine cycle of a CSP plant. Firstly, the performance modelling of each individual components and of the system as a whole will be described under ideal operating conditions (as indicated in Fig. 1). Then a parametric study on various influencing factors will be performed so as to identify appropriate functioning points for different integration concepts towards performance comparison.

\subsection{Performance modelling}

The performance analysis is based on the conservation of mass and energy. To simplify the calculation, the following assumptions are made, while the influences of certain factors will be discussed through the parametric study in the later section. Note that the solar receiver and the solar tower have not been included in the current analysis. It is supposed that the solar field provides 
the required amount of thermal energy for the power production of the Rankine cycle and the TES during the charging stage.

(A1) Steady-state operation;

(A2) Isentropic compression and expansion processes $\left(\eta_{i s e n}=1\right)$;

(A3) Evaporation and condensation at constant pressure;

(A4) Negligible heat loss; negligible pressure drop of piping system;

(A5) During the charging, the water vapor at $500{ }^{\circ} \mathrm{C}$ and $0.1 \mathrm{MPa}$ is released from the TCS reactor; during the discharging, the saturated vapor $\left(100^{\circ} \mathrm{C}, 0.1 \mathrm{MPa}\right)$ is injected into the TCS reactor; $100 \%$ conversion rate of the TCS reactor $(\gamma=1)$, no mass leakage during the storage;

(A6) The power output rate from the turbine of the principal Rankine circuit $W_{T 1}=100 \mathrm{MW}_{\mathrm{el}}$. 
Table I. Mass and energy conservation equations for the performance modelling of Rankine cycle with or without TCS integration.

\begin{tabular}{|c|c|c|c|c|c|c|c|c|c|}
\hline & & \multirow{2}{*}{$\begin{array}{l}\text { Reference } \\
\text { case }\end{array}$} & \multicolumn{2}{|c|}{ Thermal Int. } & \multicolumn{2}{|c|}{ Mass Int. } & \multicolumn{2}{|c|}{ Turbine Int. } & \multirow{2}{*}{ Note } \\
\hline & Component & & charging & discharging & charging & discharging & charging & discharging & \\
\hline \multirow{6}{*}{ 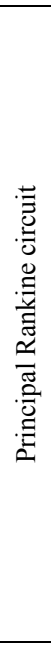 } & $\begin{array}{l}\text { Turbine } 1 \\
\text { (T1) }\end{array}$ & \multicolumn{7}{|c|}{$\begin{array}{c}T_{T 1}^{\text {in }}=480{ }^{\circ} \mathrm{C}, P_{T 1}^{\text {in }}=8.0 \mathrm{MPa} ; P_{T 1}^{\text {out }}=0.008 \mathrm{MPa} ; P_{T 1}^{\text {ext }}=0.08 \mathrm{MPa} \\
W_{T 1, C(D)}=m_{\text {Rankine }, C(D)}\left[\left(h_{T 1}^{\text {in }}-h_{T 1}^{\text {ext }}\right)+\left(1-y_{C(D)}\right)\left(h_{T 1}^{\text {ext }}-h_{T 1}^{\text {out }}\right)\right] \\
\eta_{T 1, C(D)}=\frac{h_{T 1}^{\text {ext }}-h_{11}^{\text {in }}}{h_{T 1, i s e n}^{\text {ext }}-h_{T 1}^{\text {in }}}=\frac{h_{T 1}^{\text {out }}-h_{T 1}^{\text {ext }}}{h_{T 1, i s e n}^{\text {out }}-h_{T 1}^{\text {ext }}}\end{array}$} & N1 \\
\hline & $\begin{array}{l}\text { Condenser } \\
1 \text { (CON1) }\end{array}$ & \multicolumn{7}{|c|}{$\begin{array}{c}Q_{C O N 1, C(D)}=m_{\text {Rankine } C(D)}\left(1-y_{C(D)}\right)\left(h_{C O N 1}^{i n}-h_{C O N 1}^{\text {out }}\right) \\
P_{C O N 1}^{\text {in }}=P_{C O N 1}^{\text {out }}\end{array}$} & $\mathrm{N} 2$ \\
\hline & $\begin{array}{l}\text { Pump } 1 \\
\text { (P1) }\end{array}$ & \multicolumn{7}{|c|}{$\begin{array}{c}W_{P 1, C(D)}=m_{\text {Rankine }, C(D)}\left(1-y_{C(D)}\right)\left(h_{P 1}^{\text {out }}-h_{P 1}^{\text {in }}\right) \\
\eta_{P 1, C(D)}=\frac{h_{P 1, i s e n}^{\text {out }}-h_{P 1}^{\text {in }}}{h_{P 1}^{\text {ost }}-h_{P 1}^{i p}} \text { (7) }\end{array}$} & N3 \\
\hline & $\begin{array}{c}\text { Feedwater } \\
\text { heater }(\mathrm{FH})\end{array}$ & \multicolumn{3}{|c|}{$\begin{array}{c}y_{C(D)} h_{F H}^{i n 1}+\left(1-y_{C(D)}\right) h_{F H}^{i n 2}=h_{F H}^{\text {out }} \\
P_{F H}^{i n 1}=P_{F H}^{\text {in2 }}=P_{F H}^{\text {out }} \\
\text { (9) }\end{array}$} & (1) & \multicolumn{3}{|c|}{$\begin{array}{l}(8) \\
(9) \\
\end{array}$} & \\
\hline & $\begin{array}{l}\text { Pump } 2 \\
\text { (P2) }\end{array}$ & \multicolumn{7}{|c|}{$\begin{array}{c}W_{P 2, C(D)}=m_{\text {Rankine, } C(D)}\left(h_{P 2}^{\text {out }}-h_{P 2}^{\text {in }}\right) \\
\eta_{P 2, C(D)}=\frac{h_{P 2 \text { out isen }}^{\text {out }}-h_{P 2}^{\text {in }}}{h_{P 2}^{\text {out }}-h_{P 2}^{\text {in }}}\end{array}$} & $\mathrm{N} 4$ \\
\hline & $\begin{array}{l}\text { Steam } \\
\text { generator } \\
\text { (SG) }\end{array}$ & \multicolumn{2}{|c|}{$\begin{array}{c}Q_{S G}=m_{\text {Rankine }}\left(h_{S G}^{\text {out }}-h_{S G}^{\text {in }}\right) \\
P_{S G}^{\text {in }}=P_{S G}^{\text {out }} \\
\text { (13) }\end{array}$} & - & (12) & - & $\begin{array}{l}(12) \\
(13)\end{array}$ & - & \\
\hline \multirow{5}{*}{ 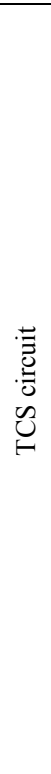 } & TCS reactor & - & $\gamma Q_{R, C}=\underset{(14)}{m_{T C S, C} \Delta h_{R}}$ & $\begin{array}{c}Q_{R, D}= \\
\gamma m_{T C S, D}\left(h_{R, D}^{\text {out }}-h_{R, D}^{\text {in }}\right) \\
(15)\end{array}$ & (14) & (15) & (14) & (15) & \multirow[t]{2}{*}{ N5 } \\
\hline & & & \multicolumn{6}{|c|}{$\begin{array}{c}m_{T C S, C} H_{C}=m_{T C S, D} H_{D}(16) \\
Q_{R, C}=Q_{R, D}+m_{T C S, D}\left(h_{T C S, S \text { steam }}^{500{ }^{\circ} \mathrm{C}}-h_{\text {TCS,steam }}^{100^{\circ} \mathrm{C}}\right)(17)\end{array}$} & \\
\hline & $\begin{array}{l}\text { Condenser } \\
2(\mathrm{CON} 2)\end{array}$ & - & $\begin{array}{c}Q_{C O N 2}= \\
m_{T C S, C}^{\text {in }} \text { (hON2 } \\
\left.h_{C O N 2}^{\text {out }}\right)(18) \\
P_{C O N 2}^{\text {in }}=P_{C O N 2}^{\text {out }}= \\
0.1 \mathrm{MPa}(19)\end{array}$ & - & $\begin{aligned} & (18) \\
& P_{C O N 2}^{\text {in }}=P_{C O N 2}^{\text {out }} \\
= & 0.008 \mathrm{MPa}(20)\end{aligned}$ & (2) & $\begin{array}{l}(18) \\
(20)\end{array}$ & - & \\
\hline & $\begin{array}{l}\text { Heat } \\
\text { exchanger } 1 \\
\text { (HX1) }\end{array}$ & - & $\begin{array}{c}h_{H X 1, R a n k i n e}^{\text {out }}= \\
\frac{m_{T C S, C}}{m_{\text {Rankine, }}}\left(h_{H X 1, T C S}^{X}-\right. \\
\left.h_{H X 1, T C S}^{\text {in }}\right)^{+} \\
h_{H X 1, R a n k i n e}^{Y}(21) \\
h_{H X 1, T C S}^{\text {out }}= \\
\frac{m_{\text {Rankine, }}}{m_{T C S, C}}\left(h_{H X 1, \text { Rankine }}^{Y}\right. \\
\left.h_{H X 1, \text { Rankine }}^{\text {in }}\right)+ \\
h_{H X 1, T C S}^{X}(22) \\
\end{array}$ & - & $\begin{array}{l}(21) \\
(22)\end{array}$ & - & - & - & N6 \\
\hline & $\begin{array}{l}\text { Heat } \\
\text { exchanger } 2 \\
\text { (HX2) }\end{array}$ & - & - & $\begin{array}{l}m_{T C S, D}\left(h_{H X 2, T C S}^{\text {out }}-\right. \\
\left.\quad h_{H X 2, T C S}^{\text {in }}\right)=\end{array}$ & - & (23) & - & (23) & \\
\hline
\end{tabular}




\begin{tabular}{|c|c|c|c|c|c|c|c|}
\hline & & $\begin{array}{c}y_{D} m_{\text {Rankine }, D}\left(h_{H X 2, R a n k i}^{\text {in }}\right. \\
\left.h_{H X 2, \text { Rankine }}^{\text {out }}\right) \\
(23)\end{array}$ & & & & & \\
\hline $\begin{array}{l}\text { Water } \\
\text { reservoir } \\
\text { (WS) }\end{array}$ & - & Saturated water at $0.1 \mathrm{MPa}$ & \multicolumn{2}{|c|}{ Saturated water at $0.008 \mathrm{MPa}$} & \multicolumn{2}{|c|}{ Sub-saturated water $\left(41.5^{\circ} \mathrm{C}\right)$ at $0.1 \mathrm{MPa}$} & N7 \\
\hline $\begin{array}{c}\text { Throttle } \\
\text { valve (TV) }\end{array}$ & - & - & $\begin{array}{c}h_{T V}^{\text {in }}=h_{T V}^{\text {out }} \\
P_{T V}^{\text {in }}=0.1 \mathrm{MPa} ; P_{T V}^{\text {out }}=0.008 \mathrm{MPa} \\
(24)\end{array}$ & - & - & - & \\
\hline $\begin{array}{l}\text { Pump } 3 \\
\text { (P3) }\end{array}$ & - & - & 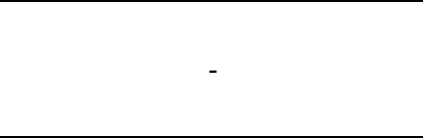 & \multicolumn{2}{|c|}{$\begin{array}{c}P_{P 3}^{\text {in }}=0.008 \mathrm{MPa} ; P_{P 3}^{\text {out }}=0.1 \mathrm{MPa} \\
W_{P 3, C(D)}=m_{T C S, C(D)}\left(h_{P 3}^{\text {out }}-h_{P 3}^{\text {in }}\right) \\
\eta_{P 3, C(D)}=\frac{h_{P, i \text { isen }}^{\text {out }}-h_{P 3}^{\text {in }}}{h_{P 3}^{\text {out }}-h_{P 3}^{i n}}(26)\end{array}$} & - & \\
\hline $\begin{array}{l}\text { Turbine } 2 \\
\text { (T2) }\end{array}$ & - & - & - & - & $\begin{array}{c}P_{T 2}^{\text {out }}=0.008 \mathrm{MPa} \\
W_{T 2}=m_{T C S}\left(h_{T 2}^{\text {in }}-h_{T 2}^{\text {out }}\right) \\
\eta_{T 2}=\frac{h_{T 2}^{\text {out }}-h_{T 2}^{\text {in }}}{h_{T 2, i s e n}^{\text {out }}-h_{T 2}^{\text {in }}}(28)\end{array}$ & - & \\
\hline $\begin{array}{l}\text { Overall energy } \\
\text { efficiency of the } \\
\text { installation }\end{array}$ & $\begin{array}{c}\eta_{o}= \\
\frac{W_{T 1}-W_{P 1}-W_{P 2}}{Q_{S G}} \\
(29)\end{array}$ & $\begin{array}{c}\eta_{o}=\frac{\left(W_{T 1, C}-W_{P 1, C}-W_{P 2, C}\right) H_{C}+\left(W_{T 1, D}-W_{P 1, D}-W_{P 2, D}\right) H_{D}}{\left(Q_{S G}+Q_{R, C}\right) H_{C}} \\
(30)\end{array}$ & \multicolumn{2}{|c|}{$\begin{array}{c}\eta_{o}= \\
\frac{\left(W_{T 1, C}-W_{P 1, C}-W_{P 2, C}\right) H_{C}+\left(W_{T 1, D}-W_{P 1, D}-W_{P 2, D}-W_{P 3, D}\right) H_{D}}{\left(Q_{S G}+Q_{R, C}\right) H_{C}} \\
(31)\end{array}$} & \multicolumn{2}{|c|}{$\begin{array}{c}\eta_{o}= \\
\frac{\left(W_{T 1, C}+W_{T 2, C}-W_{P 1, C}-W_{P 2, C}-W_{P 3, C}\right) H_{C}+\left(W_{T 1, D}-W_{P 1, D}-W_{P 2, D}\right) H_{D}}{\left(Q_{S G}+Q_{R, C}\right) H_{C}} \\
(32)\end{array}$} & N8 \\
\hline \multicolumn{8}{|c|}{$\begin{array}{l}\text { N1: saturated steam at the turbine extraction; } y_{C}=0 \text { for Mass Int. concept. } \\
\text { N2: } y_{C}=0 \text { for Mass Int. concept. } \\
\text { N3: saturated water at the inlet of P1; } y_{C}=0 \text { for Mass Int. concept. } \\
\text { N4: } T_{P 2}^{i n}=41.6{ }^{\circ} \mathrm{C} \text { for the discharging stage of Thermal Int. and Mass Int.; saturated water for the rest of concepts. } \\
\text { N5: } H_{C} \text { and } H_{D} \text { are the number of operating hours for charging and for discharging, respectively; } \gamma \text { is the conversion rate of the TCS reactor; Eq. (15) implies that a portion of reaction heat is consumed to heat the } \\
\text { saturated vapor }\left(100{ }^{\circ} \mathrm{C} 0.1 \mathrm{MPa}\right) \text { to the equilibrium temperature of reaction }\left(500{ }^{\circ} \mathrm{C} 0.1 \mathrm{MPa}\right) . \\
\text { N6: } X \text { and } Y \text { are intermediate points located at the hot side (TCS) and cold side (Rankine) of the HX1, respectively; saturated steam at } X \text { point; } T_{H X 1, T C S}^{o u t}-T_{H X 1, R a n k i n e}^{Y}=5{ }^{\circ} \mathrm{C} \text { (pinch point of } \mathrm{HX1)} \text {. } \\
\text { N7: no thermal losses during the storage period. } \\
\text { N8: } Q_{S G} \text { and } Q_{R C} \text { are the amount of heat provided by the HTF; the solar field (solar receiver) is not included in the analysis. }\end{array}$} \\
\hline
\end{tabular}


Mass and energy conservation equations for the individual components and for the whole system of different concepts are listed in Table 1. Values of thermodynamic properties of water and steam are determined referring to NIST-JANAF Thermochemical Tables [Chase, 1998]. Detailed values of main status points of the Rankine cycle with or without TCS integration may be found in the supplementary material of this paper.

Following this modeling procedure, the global performance of three proposed integration concepts is analyzed and compared with that of conventional Rankine cycle without storage (reference case). The charging/discharging scenarios examined cover a large variety of operation possibilities, for the charging time $\left(H_{C}\right)$ varying from 1 hour to 12 hours and the discharging time $\left(H_{D}\right)$ varying from 0 hour to 13 hours.

Figure 6 shows the overall energy efficiency of the installation $\left(\eta_{0}\right)$ for different integration concepts under the above-mentioned ideal operational conditions, for various charging (Fig. 6b) and discharging (Fig. 6a) scenarios. $\eta_{0}$ is defined as the total net output work of the Rankine cycle (during charging and discharging) divided by all the energy absorbed from the HTF of the solar circuit (during charging), as indicated in Eqs. 29-32.

It can be observed from Fig. 6a that for a given charging time $\left(H_{C}=11 \mathrm{~h}\right)$, the values of $\eta_{O}$ with TCS integration are lower than that of the reference case $\left(\eta_{o,}\right.$ ref $\left.=0.42\right)$ without TCS. This can be explained by the loss of a part of the energy contained in the superheated vapor produced by the TCS reactor during the charging hours. A large part of the energy is recovered/valorized via the heat exchanger 1 (Thermal Int. and Mass Int.) and via the turbine 2 (Turbine Int.). But still, a small part is lost in the condenser 2. It can also be observed in Fig. 6a that the Turbine Int. has the highest $\eta_{0}$ while the Mass Int. has the lowest. This difference becomes more important with the increasing number of discharging hours. Figure $6 \mathrm{~b}$ shows that for a given discharging time $\left(H_{D}=12 \mathrm{~h}\right)$, the $\eta_{O}$ of all concepts of TCS integration increases when the number of charging hours $\left(H_{C}\right)$ increases. It seems that a low $H_{D} / H_{C}$ ratio is favorable to achieve high values $\eta_{O}$ when TCS unit is integrated into the CSP plant.

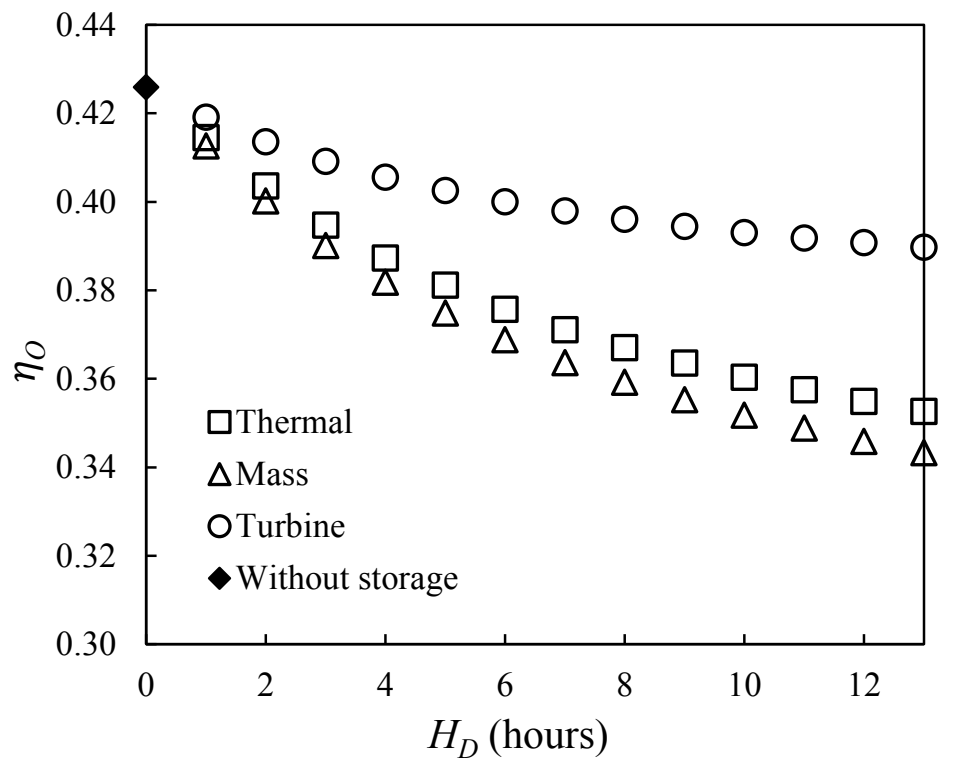

(a) 


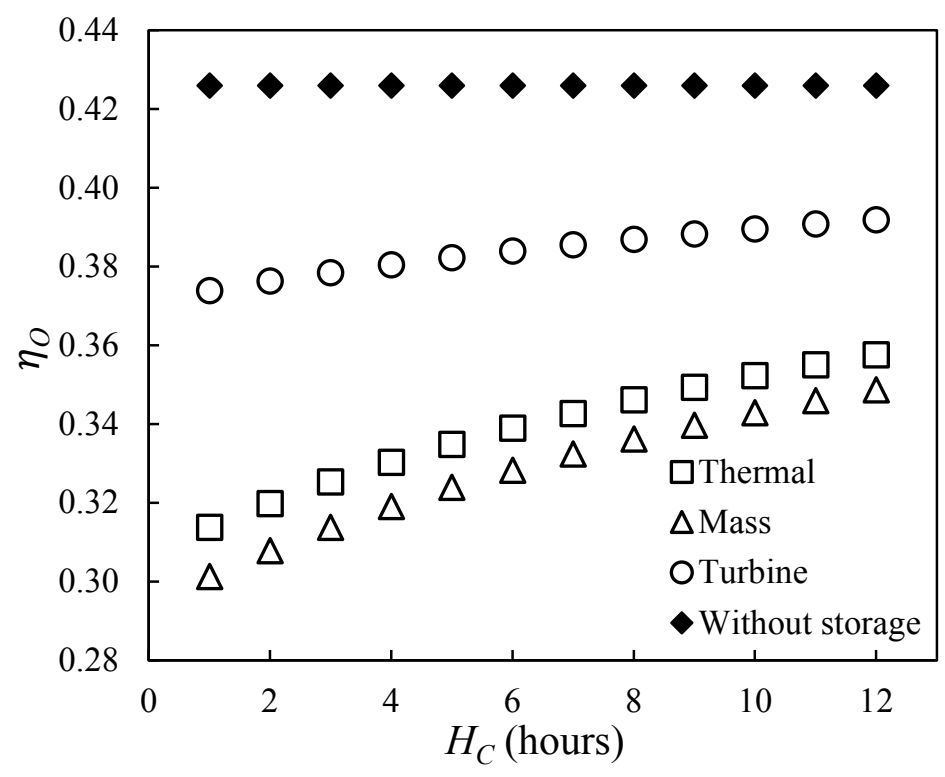

(b)

Figure 6. Overall energy efficiency of the installation $\left(\eta_{0}\right)$ for different integration concepts under ideal operational conditions. (a) different number of discharging hours $\left(H_{C}=11 \mathrm{~h}\right)$; (b) different number of charging hours $\left(H_{D}=12 \mathrm{~h}\right)$.

However, longer discharging shows clear advantages in terms of higher dispatchability and higher total power output. As shown in Fig. 7, the daily power output of Turbine Int. could reach $3010 \mathrm{MWh}$ el for 11 hours of charging and 13 hours of discharging (round-the-clock operation), which is augmented by a factor of 2.7 compared to that of the reference case without storage (only 11 hours daily production). The benefits of TCS integration into the CSP plant are therefore highlighted. In real world practice, the operation strategy of the TCS unit certainly deserves detailed investigations by taking various influencing factors into account (e.g., climate condition for charging hour, electricity demand profile for the discharging hour, hourly electricity price for techno-economic consideration, etc.).

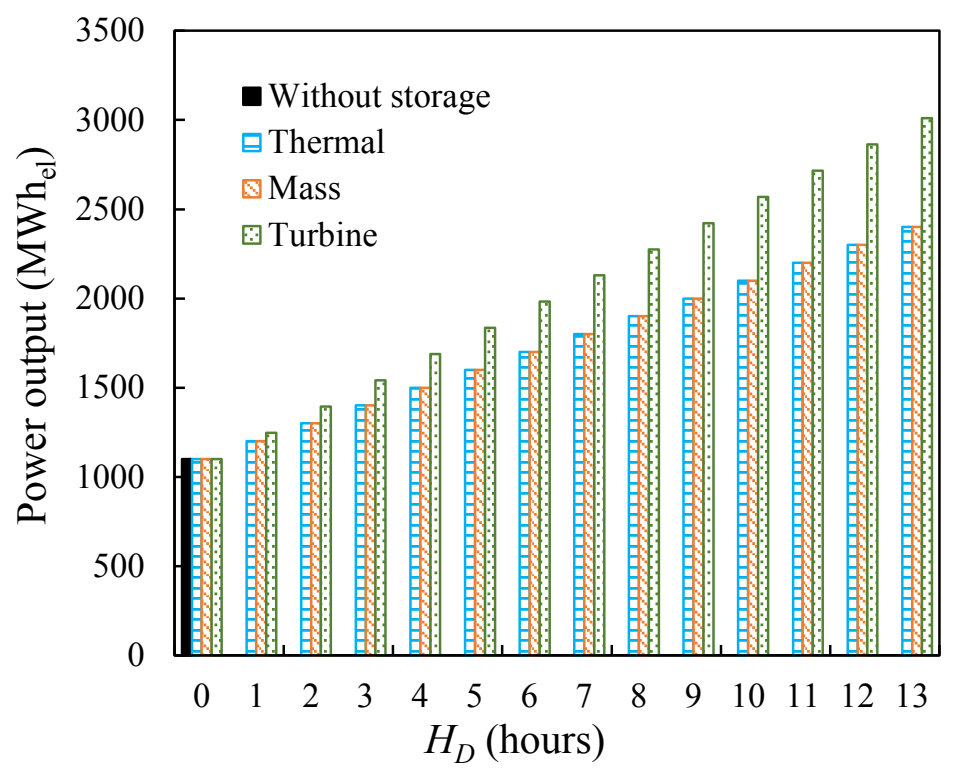

Figure 7. Power production of CSP plants as a function of the number of discharging hours $\left(H_{c}=\mid I h\right)$. 


\subsection{Parametric study}

It should be noted that in section 4.1, the overall energy efficiency is estimated under ideal conditions, neglecting all the losses. From the viewpoint of real-world engineering, it is necessary to evaluate the real performances when actual operational conditions differ from the ideal one. In this section, the impacts of various influencing factors on the overall energy efficiency of the plant are analyzed and discussed. The studied parameters include the isentropic efficiency of turbomachines (turbines and pumps), the steam temperature at the inlet of turbine 1 and the global efficiency of the TCS reactor. Note that to evaluate the separate effect of a certain parameter, only the concerned parameter is varied while others are kept as the ideal operational conditions used for performance modelling in section 4.1 .

\section{- Isentropic efficiency of turbomachines $\eta_{i s e n}$}

We define the parameter $\eta_{\text {isen }}$ as the isentropic efficiency of turbine or pumps, to represent non-isentropic compression or expansion processes. Different values of $\eta_{\text {isen }}$ from 0.5 to 1.0 are tested and added to the relevant energy conservation equations for turbines and pumps to determine the values of main status points of the cycle. Note that for simplification purpose, the equal value of $\eta_{\text {isen }}$ is assumed for all turbomachines.

Figure 8 represents the variation of $\eta_{0}$ values for different concepts as a function of the isentropic efficiency of turbomachines. The negative effect of non-isentropic compression/expansion of turbines and pumps can be clearly observed. Each $10 \%$ decrement of $\eta_{\text {isen }}$ results in about 4.2 $4.5 \%$ reduction in the $\eta_{O}$.

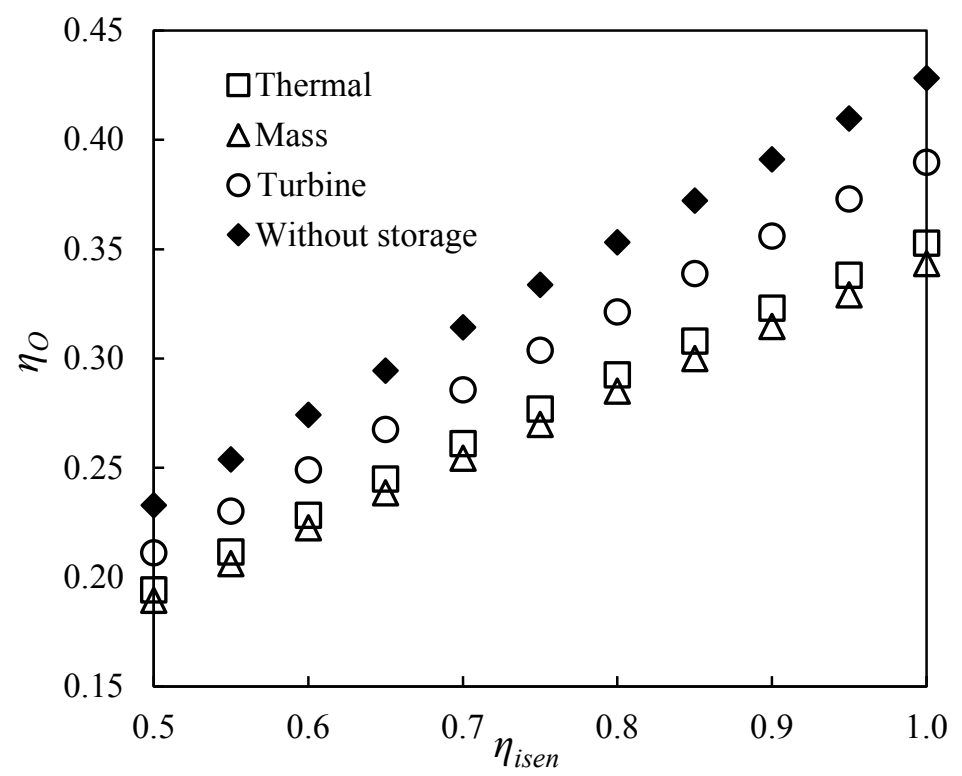

Figure 8. Overall energy efficiency $\left(\eta_{0}\right)$ as a function of the isentropic efficiency $\left(\eta_{\text {isen }}\right)$ of turbines and pumps $\left(H_{c}=1 \mathrm{I}\right.$ h; $\left.H_{D}=13 \mathrm{~h}\right)$. 
- Steam temperature at the inlet of turbine 1

Increasing the steam temperature at the inlet of turbine $1\left(T_{T 1}^{i n}\right)$ means the increased temperature of the superheated steam at the outlet of the steam generator (during charging) and the TCS reactor (during discharging). This usually leads to the augmented turbine work output. It may be observed from Fig. 9 that the $\eta_{O}$ value increases almost linearly with the increasing $T_{T 1}^{\text {in }}$ for all the studied concepts.

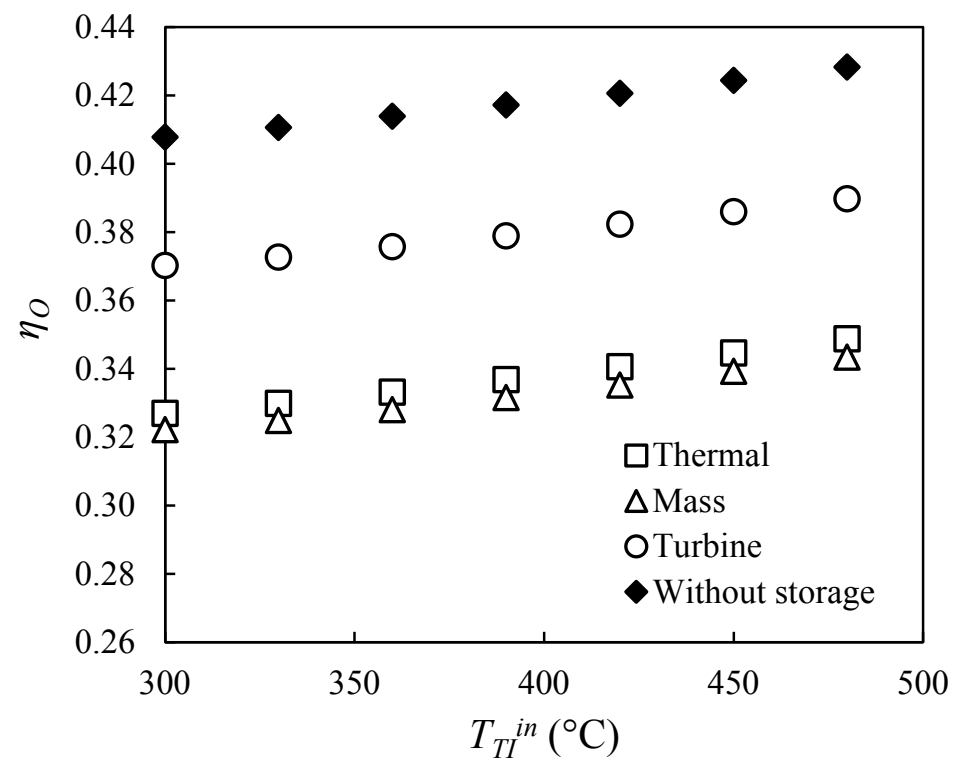

Figure 9. Overall energy efficiency $(\eta 0)$ as a function of the steam inlet temperature of the turbine $\mathrm{Tl}\left(H_{C}=I \mathrm{l}\right.$; $\left.H_{D}=\mid 3 \mathrm{~h}\right)$.

However, an excessive increase of $T_{T 1}^{i n}$ may cause the turbine damage. Moreover, higher $T_{T 1}^{i n}$ requires higher HTF temperature of the solar circuit during the charging and the higher reaction temperature of the TCS reactor during the discharging. Since the equilibrium temperature of $\mathrm{Ca}(\mathrm{OH})_{2}$ synthesis is related to the pressure (e.g., $540{ }^{\circ} \mathrm{C}$ at $0.2 \mathrm{MPa}$ ) [Schaube 2012; Zhang 2016], the TCS reactor may have to be pressurized to render higher reaction temperature. This imposes a higher requirement on the TCS reactor design and operation as well as the more complicated control strategy for the whole installation. As a result, $T_{T 1}^{\text {in }}=480{ }^{\circ} \mathrm{C}\left(500^{\circ} \mathrm{C}, 0.1 \mathrm{MPa}\right.$ for the TCS reactor) is selected as an appropriate operational parameter.

\section{- TCS reactor efficiency $\gamma$}

Another influencing factor is the reactor's efficiency, which is defined as the ratio of the effective heat released to the theoretical reaction heat for discharging, or the ratio of the theoretical heat needed to the effective heat absorbed for charging. This factor is closely linked with various aspects including the structure and size of the reactor, the reversibility of the TCS reaction and the chemical stability of the stored materials. Since it is difficult at this stage to quantify the respective impact of each aspect, we introduce the parameter $\gamma$ as the global TCS reactor efficiency taking all 
the related effects into account. We also assume identical $\gamma$ for charging and for discharging, as indicated in Table 1. Note that the assumption of constant and identical $\gamma$ values may not be appropriate in real practice, since the reversibility of the $\mathrm{CaO} / \mathrm{Ca}(\mathrm{OH})_{2}$ pair will decrease with the increasing number of operation cycles.

Figure 10 shows the calculated results of $\eta_{0}$ as a function of the global TCS reactor efficiency $\gamma$. It can be observed that the $\eta_{0}$ value decreases with the reduced global reactor efficiency. When $\gamma$ of the TCS reactor drops from 1.0 to 0.8 , the $\eta_{0}$ value decreases about $5 \%$ for Turbine Int., and about 7\% for Mass Int. and for Thermal Int. Turbine Int. concept still has the best overall energy efficiency.

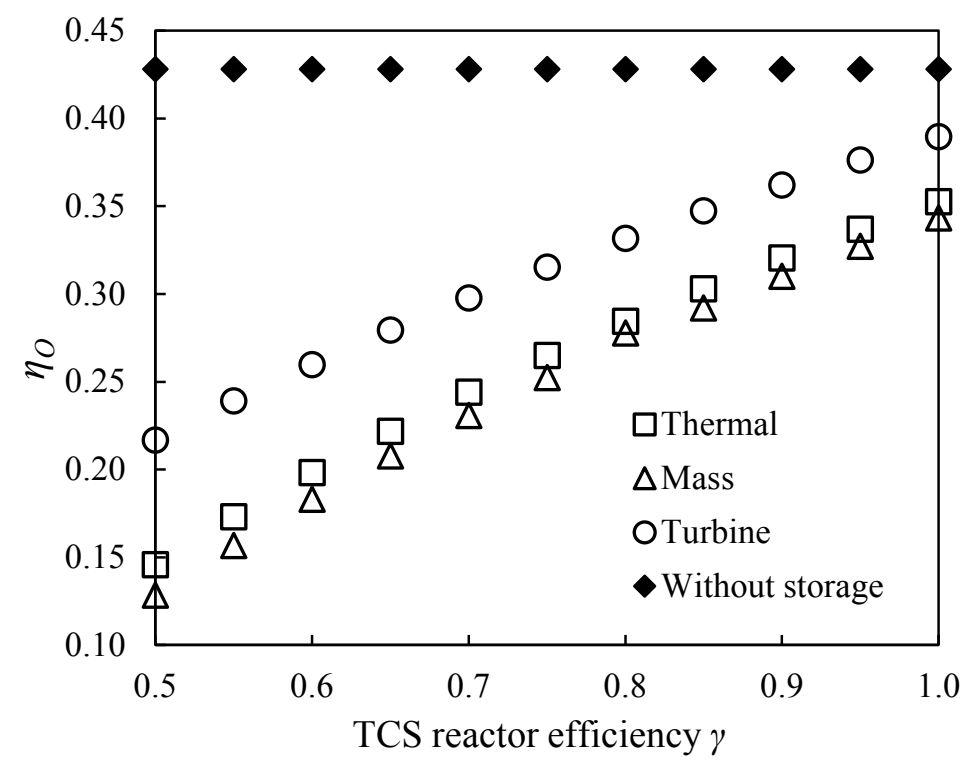

Figure 10. Overall energy efficiency $\left(\eta_{0}\right)$ as a function of the TCS reactor efficiency $\vee\left(H_{C}=I \mathrm{I}\right.$; $\left.H_{D}=I 3 \mathrm{~h}\right)$.

Besides the negative impact on the overall energy efficiency, the losses that we studied will also increase the amount of storage materials needed, thus requiring a larger size of the TCS reactor for their storage and operation. In real world engineering, special attention should be given to avoid or minimize the losses to a lower limit.

\subsection{Comparison of 3 proposed integration concepts}

The parametric study carried out in section 4.2 permits evaluating the impacts of some influencing factors on the overall energy efficiency and determining more realistic operational conditions with respect to the ideal conditions used for performance modelling in section 4.1. Based on the results obtained, a comparison of the three proposed integration concepts under more realistic operational conditional is presented in Table 2 . Note that detailed values of various parameters are obtained under the assumptions of $\eta_{\text {isen }}=0.85, T_{T 1}^{i n}=480{ }^{\circ} \mathrm{C}, \gamma=0.95, W_{T 1, C(D)}=100 \mathrm{MW}$ and round-clock operation $\left(H_{C}=11 \mathrm{~h} ; H_{D}=13 \mathrm{~h}\right)$. 
A size estimation of the TCS unit has been made and the results are recapitulated in Table 2. It is shown that the Thermal Int. concept needs a smaller quantity of TCS material (9571 t) than the Mass Int. (10013 t) and the Turbine Int. (9998 t) for 13 hours discharging time. It is because the water vapor from the TCS reactor is stored as saturated liquid $\left(100^{\circ} \mathrm{C}, 0.1 \mathrm{MPa}\right)$ for the Thermal Int. whereas for Mass Int. and Turbine Int. concepts, the water is stored at $41.5^{\circ} \mathrm{C}$. Therefore, a bit more quantity of TCS materials is needed for the latter two concepts to compensate this temperature difference. 
Table 2. Comparison on the energy performance of three proposed integration concepts under more realistic operating conditions $\left(\eta_{\text {isen }}=0.85, T_{T 1}^{i n}=480{ }^{\circ} \mathrm{C}, \nu=0.95, W_{T 1, C(D)}=\right.$ $100 \mathrm{MW}$ and round-clock operation $\left(H_{c}=1 \mathrm{I} \mathrm{h} ; H_{D}=13 \mathrm{~h}\right)$.

\begin{tabular}{|c|c|c|c|c|c|c|c|c|c|c|c|c|c|c|c|c|}
\hline & & \multirow[b]{2}{*}{$\eta_{O}$} & \multicolumn{3}{|c|}{ Operational data } & \multirow[b]{2}{*}{$\begin{array}{l}\text { SG } \\
\text { (MW) }\end{array}$} & \multicolumn{5}{|c|}{ Heat exchange rate } & \multicolumn{3}{|c|}{ Work exchange rate } & \multicolumn{2}{|c|}{ Size of storage unit } \\
\hline & & & $\begin{array}{l}m_{\text {Rankine }} \\
\left(\mathrm{kg} \cdot \mathrm{s}^{-1}\right)\end{array}$ & $\begin{array}{c}m_{T C S} \\
\left(\mathrm{~kg} \cdot \mathrm{s}^{-1}\right)\end{array}$ & $y$ & & $\begin{array}{l}\text { CON1 } \\
\text { (MW) }\end{array}$ & $\begin{array}{l}\text { CON2 } \\
\text { (MW) }\end{array}$ & $\begin{array}{l}\text { HX2 } \\
(\mathrm{MW})\end{array}$ & $\begin{array}{l}\text { HX1 } \\
\text { (MW) }\end{array}$ & $\begin{array}{l}\text { R } \\
\text { (MW) }\end{array}$ & $\begin{array}{l}\text { T1 } \\
\text { (MW) }\end{array}$ & $\begin{array}{l}\mathrm{T} 2 \\
\text { (MW) }\end{array}$ & $\begin{array}{l}\mathrm{P} 1+2+3 \\
(\mathrm{MW})\end{array}$ & $\begin{array}{l}\text { Mass of } \\
\text { water } \\
\text { stored (t) }\end{array}$ & $\begin{array}{l}\text { Mass of } \\
\mathrm{CaO} \\
\text { stored (t) }\end{array}$ \\
\hline \multirow[t]{2}{*}{$\begin{array}{l}\text { Thermal } \\
\text { Int. }\end{array}$} & Discharging & 0.295 & 144 & 80 & 0.67 & - & 78.0 & - & 181.4 & - & 378.7 & 100 & - & 1.0 & 3079 & 9571 \\
\hline & Charging & & 91 & 95 & 0 & 190.8 & 188.7 & 194.4 & - & 97.3 & 548.3 & 100 & - & 0.6 & & \\
\hline \multirow{2}{*}{$\begin{array}{l}\text { Mass } \\
\text { Int. }\end{array}$} & Discharging & & 151 & 84 & 0.72 & - & 87.0 & - & 210.3 & - & 396.2 & 100 & - & 1.0 & 3221 & 10013 \\
\hline & Charging & & 91 & 99 & 0 & 187.1 & 188.8 & 228.3 & - & 121.2 & 573.7 & 100 & - & 0.6 & & \\
\hline \multirow{2}{*}{$\begin{array}{l}\text { Turbine } \\
\text { Int. }\end{array}$} & Discharging & & 151 & 84 & 0.72 & - & 87.1 & - & 210.0 & - & 395.6 & 100 & - & 1.50 & 3217 & 9998 \\
\hline & Charging & & 102 & 92 & 0.20 & 268.3 & 169.4 & 251.4 & - & - & 531.6 & 100 & 53.7 & 1.0 & & \\
\hline
\end{tabular}


The energy storage density is roughly estimated to be about $100 \mathrm{kWh}_{\mathrm{el}} \mathrm{t}^{-1}$. This value is about seven times higher than that of existing CSP plants using molten salt as energy storage media (eg. for Andasoll Spain, the heat reservoir consists of two tanks measuring $14 \mathrm{~m}$ in height and $36 \mathrm{~m}$ in diameter and containing 28500 tons of molten salts, enough to run the turbine for about 7.5 hours at $50 \mathrm{MW}_{\text {el }}$ [Pelay 2017b]. The energy storage density is calculated to be $\left.13.1 \mathrm{kWh}_{\mathrm{el}} \cdot \mathrm{t}^{-1}\right)$. Higher energy storage density implies more compact storage unit and less heat loss of the storage reservoirs.

A first comparison between the three proposed integration concepts can then be made. Firstly, the Turbine Int. concept is the most interesting $\left(\eta_{o}=0.327\right)$ in terms of overall energy efficiency. However, a second turbine is needed, implying the higher initial cost. Particular attention should be given to the purity of steam leaving the TCS reactor that may cause the mechanical failure of the second turbine. Efficient filtration measures are indispensable for dust removal as has been discussed above. Secondly, the Mass Int. concept is the least attractive $\left(\eta_{0}=0.286\right)$. In fact, the mixing of working fluids between principal Rankine circuit and the TCS circuit may not be a good option again due to the purity issue that could be vital to the turbine. Finally, the Thermal Int. concept does not possess the highest overall energy efficiency, but its simple and robust design makes it relatively easy towards implementation. Moreover, relatively small volumes of reservoirs are required based on the size estimation reported above.

\section{Exergy analysis of different TCS integration concepts}

The previous section presents a comparison of the three proposed integration concepts based on the energy analysis (first law of thermodynamics). Meanwhile, an exergy balance will also be beneficial by providing supplemental insights on the quality of the energy, taking the irreversibility notion of the processes into account [Dincer 2002; Rosen 2003; Kang 2018]. The main purpose of this section is hence to evaluate and compare the overall exergy efficiency of the three proposed integration concepts through an exergy analysis. Note that the exergy analysis and the modelling results presented hereafter are obtained under realistic operating conditions $\left(\eta_{\text {isen }}=0.85\right.$ and $\left.\gamma=0.95\right)$ as specified in sections 4.3 .

\subsection{Performance modelling for the exergy analysis}

Exergy as a thermodynamic notion means the maximum work extracted from a stream as the stream reaches the dead state [Bejan, 1988]. The total exergy of a system $E x$ includes four components, namely physical exergy, kinetic exergy, potential exergy and chemical exergy [Rosen 2003]. Neglecting the potential and kinetic exergy changes, the exergy balance of different components may be modelled as follows.

- Turbine or pump

$$
i=m T_{0} . \Delta s
$$




$$
\varepsilon=1-\dot{l} /\left(\dot{E x} x_{i n}+m \Delta h\right)
$$

- Heat exchanger

$$
\begin{aligned}
& i=-\left(\Delta \dot{E x_{h o t}}+\Delta \dot{E x} x_{\text {cold }}\right) \\
& \varepsilon=1-\dot{l} /\left(\dot{E x}_{\text {hot }_{\text {in }}}+\dot{\left.E x_{\text {cold }_{\text {in }}}\right)}\right.
\end{aligned}
$$

- Steam generator or condenser

$$
\begin{gathered}
i=m T_{0} \Delta s+\frac{T_{0}}{T} Q \\
\varepsilon=1-\dot{l} / \dot{E} x_{i n}
\end{gathered}
$$

- TCS reactor

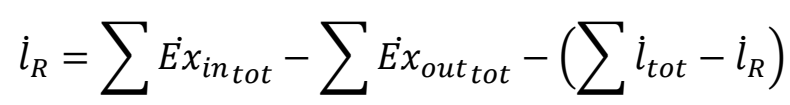

Where $h\left(\mathrm{~J} \cdot \mathrm{kg}^{-1}\right)$ is the specific enthalpy, Ex $(\mathrm{W})$ the exergy and $s\left(\mathrm{~J}^{-\mathrm{K}^{-1}} \cdot \mathrm{kg}^{-1}\right)$ the specific entropy. $l(\mathrm{~W})$ is the exergy destuction of the component and $\varepsilon$ is the exergy efficiency of the component. The overall exergy efficiency of the CSP plant $\eta_{e x}$ is defined as the ratio of the exergy extracted by turbine(s) to the amount of exergy provided by the HTF of the solar circuit.

$$
\eta_{\text {ex }}=\frac{\sum \dot{E} x_{\text {out }}}{\sum \dot{E} x_{\text {in }}}
$$

\subsection{Results and discussion}

An exergy analysis has been performed for the three proposed integration concepts. Figure 11 shows the exergy flow-chart for each integration concept comprising of both the charging and the discharging stages. Note that the reference temperature $T_{0}$ was chosen as $5{ }^{\circ} \mathrm{C}$, a value lower than those of the whole system. It allows an easier reading and interpretation of the results obtained.

The exergy flow-chart for the Thermal Int. concept is shown in Fig. 11a, indicating that the overall exergy efficiency $\left(\eta_{e x}\right)$ equals to 0.49 . It can be observed that the highest exergy destructions happen in the TCS reactor and in the heat exchanger (HX2) during discharging whereas in the steam generator, in the TCS reactor and in the condenser (CON2) during charging. These exergy destructions are mainly due to the irreversibilities caused by the large amount of heat transfer in these components. Note that exergy destructions in the reservoir and in pumps are negligible. A close look at each component indicates that the $\mathrm{CON} 2$ with a very low exergy efficiency $\left(\varepsilon_{\mathrm{CON} 2}=0.19\right)$ during charging stage is the main cause of exergy destruction. 


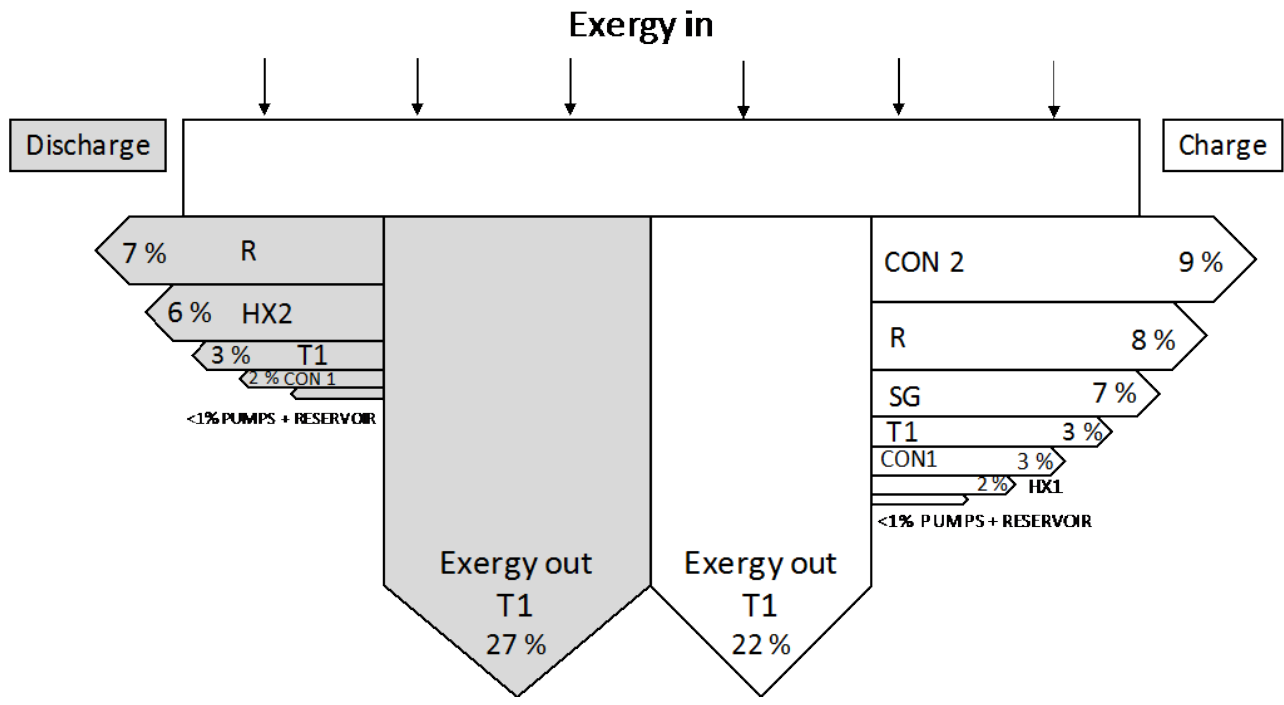

(a)

538
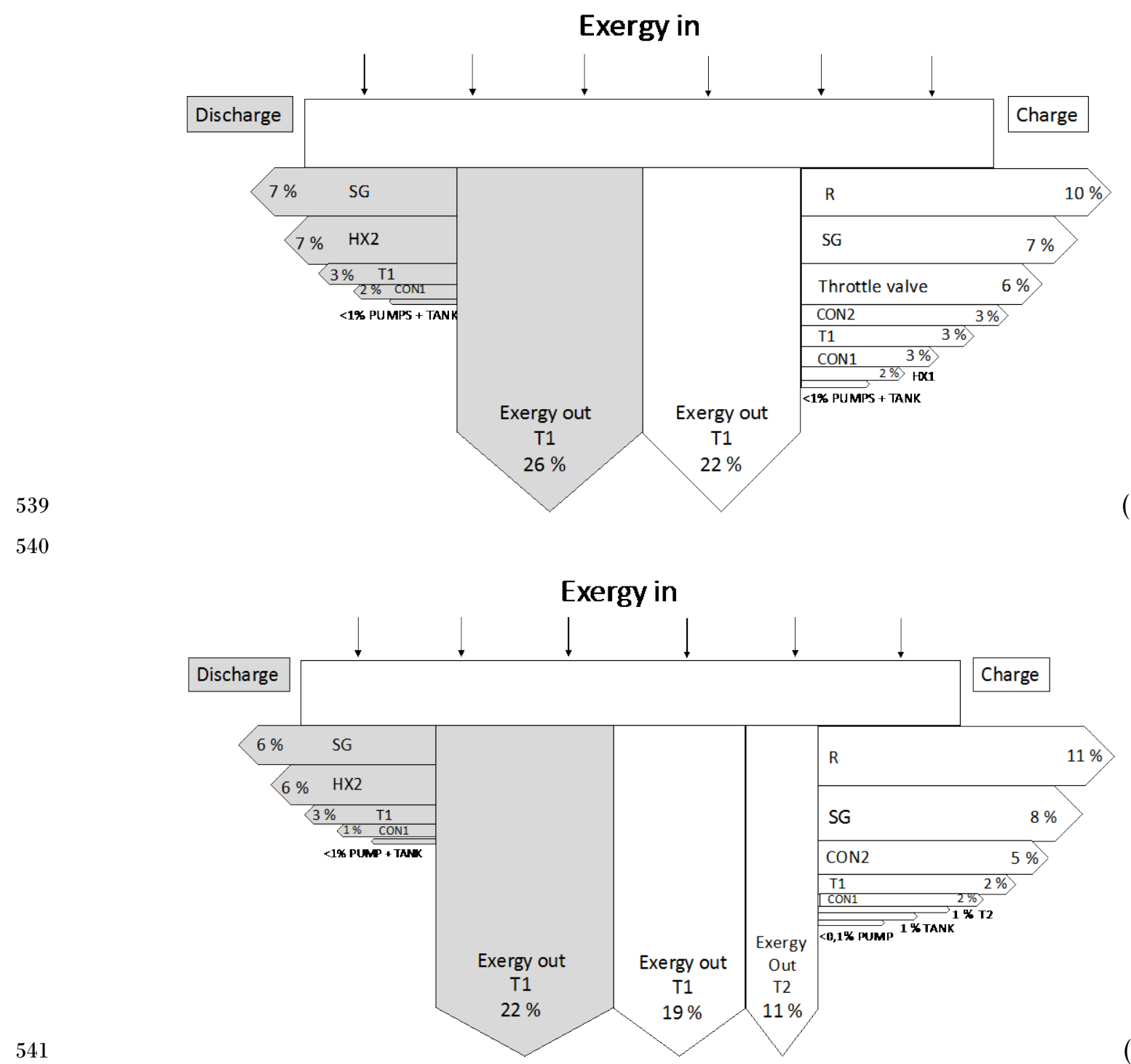

(b)

Figure II. Exergy flow-chart and overall exergy efficiency $\left(\eta_{e x}\right)$ for three proposed integration concepts. (a) Thermal integration concept; (b) Mass integration concept; (c) Turbine integration concept. 
The Mass Int. concept has a slightly lower $\eta_{e x}$ value (0.48). It can be observed from Fig. 11b that the TCS reactor is the main component of exergy destruction during charging and discharging. The HX2 during discharging, the SG and throttle valve (TV) during charging also have high exergy destructions compared to those in reservoirs or pumps. Similar to the Thermal Int. concept, these losses are mainly due to the irreversibilities caused by the large amount of heat transfer in these components. An option to improve the $\varepsilon_{\mathrm{TV}}$ is to release the fluid at a pressure higher than 0.008 MPa. Nevertheless, the condensed water should be stored separately instead of sharing a common reservoir which is the distinguishing feature of the Mass Int. concept.

The Turbine Int. concept has the highest exergy efficiency $\left(\eta_{e x}=0.52\right)$ among the three. Figure 11c indicates that the highest exergy destructions happen in the TCS reactor and in the HX2 during discharging whereas in the TCS reactor, in the SG and in the CON2 during charging. The TCS reactor represents the highest exergy destruction of the system while the CON2 has the lowest exergy efficiency $\left(\varepsilon_{\mathrm{CON} 2}=0.27\right)$.

In brief, the exergy analysis of the three proposed integration concepts confirms that, in terms of overall exergy efficiency of the installation, the Turbine Int. concept is the most attractive $\left(\eta_{e x}=0.52\right)$, followed by the Thermal Int. concept $\left(\eta_{e x}=0.49\right)$ and then the Mass Int. concept $\left(\eta_{e x}=0.48\right)$.

\section{Conclusion and prospects}

This paper presents a conceptual study of three different TCS integration concepts in a Rankine cycle driven by CSP. The TCS material used in this study is the $\mathrm{CaO} / \mathrm{Ca}(\mathrm{OH})_{2}$ couple. Based on the energy and exergy analyses, main conclusions could be reached as follows.

- Different integration concepts are feasible by coupling the TCS system with a Rankine cycle and by carefully determining flow circuit configurations and working conditions for charging and discharging stages.

- The overall energy efficiency of the installation under ideal conditions is evaluated to be 0.358 for the Thermal Int. concept, 0.349 for the Mass Int. concept and 0.392 for the Turbine Int. concept, respectively $\left(H_{C}=11 ; H_{D}=13\right)$. Compared to the reference case without storage, the TCS integration decreases the overall energy efficiency but improves the adaptability and dispatchability of CSP plants with the increased power production.

- The energy storage density using calcium hydroxide as storage media is roughly estimated to be about $100 \mathrm{kWh}_{\mathrm{e}} \cdot \mathrm{t}^{-1}$; this value is about seven times higher than that of existing CSP plant with a sensible heat storage using molten salt (about $\left.13.1 \mathrm{kWh}_{\mathrm{el}} \cdot \mathrm{t}^{-1}\right)$. 
- Different types of losses would cause a reduced overall energy efficiency of the installation. Non-isentropic compression/expansion and poor efficiency of the TCS reactor would have significant negative impacts on the overall energy efficiency.

- Among the three proposed integration concepts, the Turbine Int. concept seems to be the best option with the highest overall energy and exergy efficiencies under the tested conditions.

It should be noted that this study has focused on the integration conception issue, and promising findings have been obtained for this essential step. Nevertheless, a number of scientific \& technological barriers remain to be overcome for the real implementation of TCS systems in CSP plants. Our ongoing work includes the dynamic simulation of each individual components (including the solar receiver and the TCS reactor) and the whole installation under real conditions. The technoeconomic considerations in TCS evaluation are also our study focus, so as to assess the feasibility of such TCS integration into a real CSP plant. The results obtained on these remaining issues will be presented in future papers.

\section{Acknowledgement}

This work was supported by the French ANR within the project In-STORES (ANR-12SEED-0008). The authors also wish to thank the colleagues of laboratory PROMES (CNRS UPR 8521) also involved in this ANR project, for fruitful and inspiring discussions.

\section{Nomenclature}

\section{Latin letters}

Ex

exergy, W

$H$

charging or discharging time, $\mathrm{h}$

$h$

specific enthalpy, $\mathrm{kJ} \cdot \mathrm{kg}^{-1}$

$i \quad$ exergy destruction, $\mathrm{W}$

$m$

mass flowrate, $\mathrm{kg} \cdot \mathrm{s}^{-1}$

$n$

number of mole

$P \quad$ pressure, $\mathrm{Pa}$

$Q \quad$ heat exchange rate, $\mathrm{W}$

$s \quad$ specific entropy, $\mathrm{kJ} \cdot \mathrm{kg}^{-1} \cdot \mathrm{K}^{-1}$

$T$ temperature, ${ }^{\circ} \mathrm{C}$

$T_{0} \quad$ reference temperature, $5^{\circ} \mathrm{C}$

$W \quad$ work exchange rate, $\mathrm{W}$

mass fraction of vapor 


\begin{tabular}{|c|c|c|}
\hline 629 & $y$ & fraction of extracted steam \\
\hline 630 & $X, Y$ & intermediate points for the modeling of $\mathrm{HX} 1$ \\
\hline \multicolumn{3}{|l|}{631} \\
\hline \multicolumn{3}{|l|}{632} \\
\hline 633 & Greek symbols & \\
\hline 634 & $\gamma$ & global reactor efficiency \\
\hline 635 & $\varepsilon$ & exergy efficiency of component \\
\hline 636 & $\Delta h_{R}$ & reaction heat, $\mathrm{kJ} \cdot \mathrm{kg}^{-1}$ \\
\hline 637 & $\eta_{o}$ & overall energy efficiency \\
\hline 638 & $\eta_{\text {isen }}$ & isentropic efficiency of turbine and pumps \\
\hline 639 & $\eta_{\text {ex }}$ & overall exergy efficiency \\
\hline \multicolumn{3}{|l|}{640} \\
\hline \multicolumn{3}{|l|}{641} \\
\hline 642 & \multicolumn{2}{|c|}{ Subscripts/superscripts } \\
\hline 643 & C & charging stage \\
\hline 644 & $\mathrm{D}$ & discharging stage \\
\hline 645 & el & electricity \\
\hline 646 & ext & extraction \\
\hline 647 & in & inlet \\
\hline 648 & isen & isentropic \\
\hline 649 & out & outlet \\
\hline 650 & steam & steam \\
\hline 651 & th & thermal \\
\hline 652 & tot & total \\
\hline \multicolumn{3}{|l|}{653} \\
\hline \multicolumn{3}{|l|}{654} \\
\hline 655 & Abbreviation & \\
\hline 656 & $\mathrm{CON}$ & condenser \\
\hline 657 & CSP & concentrating solar power \\
\hline 658 & FH & feedwater heater \\
\hline 659 & HTF & heat transfer fluid \\
\hline 660 & HX & heat exchanger \\
\hline 661 & Int. & integration \\
\hline 662 & $\mathbf{P}$ & pump \\
\hline 663 & PCM & phase change material \\
\hline 664 & $\mathbf{R}$ & reactor \\
\hline 665 & Rankine & Rankine circuit \\
\hline 666 & SG & steam generator \\
\hline 667 & $\mathrm{~T}$ & turbine \\
\hline 668 & TCS & thermochemical energy storage \\
\hline 669 & TES & thermal energy storage \\
\hline 670 & TV & throttle valve \\
\hline 671 & WS & water reservoir \\
\hline
\end{tabular}




\section{References}

Alva, G., Lin, Y., \& Fang, G. (20I8). An overview of thermal energy storage systems. Energy, |44, 34|-378. https://doi.org/10.1016/j.energy.2017.12.037

Álvarez De Miguel, S., Gonzalez-Aguilar, J., \& Romero, M. (2013). 100-Wh multi-purpose particle reactor for thermochemical heat storage in concentrating solar power plants. Energy Procedia, 49, 676-683. https://doi.org/10.1016/j.egypro.2014.03.073

André, L., Abanades, S., \& Flamant, G. (2016). Screening of thermochemical systems based on solid-gas reversible reactions for high temperature solar thermal energy storage. Renewable and Sustainable Energy Reviews, 64, 703-715. https://doi.org/10.1016/j.rser.2016.06.043

Aydin, D., Casey, S. P., \& Riffat, S. (2015). The latest advancements on thermochemical heat storage systems. Renewable and Sustainable Energy Reviews, 4I, 356-367. https://doi.org/10.1016/j.rser.2014.08.054

Azpiazu, M. N., Morquillas, J. M., \& Vazquez, A. (2003). Heat recovery from a thermal energy storage based on the $\mathrm{Ca}(\mathrm{OH}) 2 / \mathrm{CaO}$ cycle. Applied Thermal Engineering, 23, 733-74I. https://doi.org/10.1016/S1359$\underline{43 I I(03) 000 I 5-2}$

Bagherisereshki, E., Tran, J., Lei, F., AuYeung, N. (2018). Investigation into SrO/SrCO3 for high temperature thermochemical energy storage. Solar Energy, 160, 85-93. https://doi.org/10.1016/j.solener.2017.11.073

Balghouthi, M., Trabelsi, S. E., Amara, M. B., Ali, A. B. H., \& Guizani, A. (2016). Potential of concentrating solar power (CSP) technology in Tunisia and the possibility of interconnection with Europe. Renewable and Sustainable Energy Reviews, 56, 1227-1248. https://doi.org/10.1016/j.rser.2015.12.052

Bejan, A. (1988). Advanced Engineering Thermodynamics, John Wiley \& Sons Inc., New York.

Cabeza, L. F., Gutierrez, A., Barreneche, C., Ushak, S., Fernández, Á. G., Inés Fernádez, A., \& Grágeda, M. (20I5). Lithium in thermal energy storage: A state-of-the-art review. Renewable and Sustainable Energy Reviews, 42, I 106-I I I2. https://doi.org/10.1016/j.rser.2014.10.096

Cabeza, L. F., Solé, A., Fontanet, X., Barreneche, C., Jové, A., Gallas, M., Fernández, A. I. (20I7). Thermochemical energy storage by consecutive reactions for higher efficient concentrated solar power plants (CSP): Proof of concept. Applied Energy, 185, 836-845. https://doi.org/10.1016/j.apenergy.2016.10.093

Cáceres, G., Anrique, N., Girard, A., Degrève, J., Baeyens, J., \& Zhang, H. L. (20I3). Performance of molten salt solar power towers in Chile. Journal of Renewable and Sustainable Energy, 5(5). https://doi.org/10.1063/1.4826883

Calderón, A., Palacios, A., Barreneche, C., Segarra, M., Prieto, C., Rodriguez-Sanchez, A., \& Fernández, A. I. (2018). High temperature systems using solid particles as TES and HTF material: A review. Applied Energy, 213, 100-III. https://doi.org/10.1016/j.apenergy.2017.12.107

Chase, M. W. Jr. (1998). NIST-JANAF Thermochemical Tables, Fourth Edition. Journal of Physical and Chemical Reference Data.

Chirino, H., Xu, B., Xu, X., \& Guo, P. (20I8). Generalized diagrams of energy storage efficiency for latent heat thermal storage system in concentrated solar power plant. Applied Thermal Engineering, 129, 1595-1603. https://doi.org/10.1016/j.applthermaleng.2017.10.153

del Río, P., Peñasco, C., \& Mir-Artigues, P. (2018). An overview of drivers and barriers to concentrated solar power in the European Union. Renewable and Sustainable Energy Reviews, 8I, I019-1029. https://doi.org/10.1016/j.rser.2017.06.038

Deutsch, M., Horvath, F., Knoll, C., Lager, D., Gierl-Mayer, C., Weinberger, P., \& Winter, F. (20I7). HighTemperature Energy Storage: Kinetic Investigations of the CuO/Cu 2 O Reaction Cycle. Energy \& Fuels, 3I (3), 2324-2334. https://doi.org/10.102I/acs.energyfuels.6b02343 
Dincer, I. (2002). Thermal energy storage systems as a key technology in energy conservation. International Journal of Energy Research, 26(7), 567-588. https://doi.org/10.1002/er.805

Dowling, A. W., Zheng, T., \& Zavala, V. M. (2017). Economic assessment of concentrated solar power technologies: A review. Renewable and Sustainable Energy Reviews, 72, 1019-1032. https://doi.org/10.1016/j.rser.2017.01.006

Dunham, M. T., \& Iverson, B. D. (20I4). High-efficiency thermodynamic power cycles for concentrated solar power systems. Renewable and Sustainable Energy Reviews, 30, 758-770. https://doi.org/10.1016/j.rser.2013.11.010

Dunn, R. I., Hearps, P. J., \& Wright, M. N. (2012). Molten-salt power towers: Newly commercial concentrating solar storage. In Proceedings of the IEEE (Vol. 100, Pp. 504-5I5). https://doi.org/10.1109/JPROC.2011.2163739

Fernandes, D., Pitié, F., Cáceres, G., \& Baeyens, J. (2012). Thermal energy storage: "How previous findings determine current research priorities." Energy, 39(I), 246-257. https://doi.org//0.1016/j.energy.2012.01.024

Gil, A., Medrano, M., Martorell, I., Lázaro, A., Dolado, P., Zalba, B., \& Cabeza, L. F. (2010). State of the art on high temperature thermal energy storage for power generation. Part I-Concepts, materials and modellization. Renewable and Sustainable Energy Reviews, I4, 31-55. https://doi.org/I0.1016/j.rser.2009.07.035

Gutierrez, A., Miró, L., Gil, A., Rodríguez-Aseguinolaza, J., Barreneche, C., Calvet, N., Cabeza, L. F. (2016). Advances in the valorization of waste and by-product materials as thermal energy storage (TES) materials. Renewable and Sustainable Energy Reviews, 59, 763-783. https://doi.org/I0.1016/j.rser.2015.12.071

IEA (20I4). Energy Technology Perspectives. París, France: IEA publications; http://www.iea.org/etp/etp20I4/.

IRENA (2016). REmap: roadmap for a renewable energy future, 2016 edition. Abu Dhabi: International Renewable Energy Agency (IRENA); 〈www.irena.org/remap).

Kang, Q., Dewil, R., Degrève, J., Baeyens, J., Zhang, H. (2018). Energy analysis of a particle suspension solar combined cycle power plant. Energy Conversion and Management, 163, 293-303. https://doi.org/10.1016/j.enconman.2018.02.067

Kuravi, S., Trahan, J., Goswami, D. Y., Rahman, M. M., \& Stefanakos, E. K. (2013). Thermal energy storage technologies and systems for concentrating solar power plants. Progress in Energy and Combustion Science, 39, 285-319. https://doi.org//0.1016/j.pecs.2013.02.001

Liu, M., Steven Tay, N. H., Bell, S., Belusko, M., Jacob, R., Will, G., Saman, W., Bruno, F. (2016). Review on concentrating solar power plants and new developments in high temperature thermal energy storage technologies. Renewable and Sustainable Energy Reviews, 53, I4||-1432. https://doi.org//0.1016/j.rser.2015.09.026

Luo, L., Fan Y., Mazet, N., Stitou, D., Mauran, S., Neveu, P. (2016). Installation de production d'électricité comprenant un stockage de chaleur. French Patent FR 1662785

Michel, B., Mazet, N., Mauran, S., Stitou, D., \& Xu, J. (2012). Thermochemical process for seasonal storage of solar energy: Characterization and modeling of a high density reactive bed. Energy, 47, 553-563. https://doi.org//0.1016/j.energy.2012.09.029

Moran, M.J., Shapiro, H.N., Munson, B.R., DeWitt, D.P., (2003). Introduction to Thermal Systems Engineering: Thermodynamics, Fluid Mechanics and Heat Transfer. John Wiley \& Sons, Inc.

Myers, P. D., \& Goswami, D. Y. (2016). Thermal energy storage using chloride salts and their eutectics. Applied Thermal Engineering, 109, 889-900. https://doi.org/10.1016/j.applthermaleng.2016.07.046 
Nithyanandam, K., \& Pitchumani, R. (20I4). Cost and performance analysis of concentrating solar power systems with integrated latent thermal energy storage. Energy, 64, 793-810. https://doi.org/10.1016/j.energy.2013.10.095

Ortega-Fernández, I., Calvet, N., Gil, A., Rodríguez-Aseguinolaza, J., Faik, A., \& D’Aguanno, B. (2015). Thermophysical characterization of a by-product from the steel industry to be used as a sustainable and low-cost thermal energy storage material. Energy, 89, 601-609. https://doi.org/10.1016/j.energy.2015.05.153

Ortiz, C., Chacartegui, R., Valverde, J. M., Alovisio, A., \& Becerra, J. A. (2017). Power cycles integration in concentrated solar power plants with energy storage based on calcium looping. Energy Conversion and Management, 149, 815-829. https://doi.org/10.1016/j.enconman.2017.03.029

Pan, Z. H., \& Zhao, C. Y. (2017). Gas-solid thermochemical heat storage reactors for high-temperature applications. Energy, 130, I55-173. https://doi.org/10.1016/j.energy.2017.04.102

Parrado, C., Cáceres, G., Bize, F., Bubnovich, V., Baeyens, J., Degrève, J., \& Zhang, H. L. (20I5). Thermomechanical analysis of copper-encapsulated NaNO3-KNO3. Chemical Engineering Research and Design, 93, 224-231. https://doi.org/10.1016/j.cherd.2014.07.007

Pardo, P., Anxionnaz-Minvielle, Z., Rougé, S., Cognet, P., \& Cabassud, M. (20/4). $\mathrm{Ca}(\mathrm{OH}) 2 / \mathrm{CaO}$ reversible reaction in a fluidized bed reactor for thermochemical heat storage. Solar Energy, 107, 605-616. https://doi.org/10.1016/j.solener.2014.06.010

Pardo, P., Deydier, A., Anxionnaz-Minvielle, Z., Rougé, S., Cabassud, M., \& Cognet, P. (20I4). A review on high temperature thermochemical heat energy storage. Renewable and Sustainable Energy Reviews, 32, 59I-6I0 https://doi.org/10.1016/j.rser.2013.12.014

Pelay, U., Luo, L., Fan, Y., Stitou, D., \& Rood, M. (2017a). Thermal energy storage systems for concentrated solar power plants. Renewable and Sustainable Energy Reviews, 79, 82-100. https://doi.org/10.1016/j.rser.2017.03.139

Pelay, U., Luo, L., Fan, Y., Stitou, D., \& Rood, M. (20I7b). Technical data for concentrated solar power plants in operation, under construction and in project. Data in Brief, 13, 597-599. https://doi.org/10.1016/j.dib.2017.06.030

Pitié, F., Zhao, C. Y., Baeyens, J., Degrève, J., \& Zhang, H. L. (20I3). Circulating fluidized bed heat recovery/storage and its potential to use coated phase-change-material (PCM) particles. Applied Energy, 109, 505-5I3. https://doi.org/10.1016/j.apenergy.2012.12.048

Prieto, C., Cooper, P., Fernández, A. I., \& Cabeza, L. F. (2016). Review of technology: Thermochemical energy storage for concentrated solar power plants. Renewable and Sustainable Energy Reviews, 60, 909-929. https://doi.org/10.1016/j.rser.2015.12.364

Rosen, M. A., \& Dincer, I. (2003). Exergy methods for assessing and comparing thermal storage systems. International Journal of Energy Research, 27(4), 4I5-430. https://doi.org/10.1002/er.885

Sakellariou, K. G., Criado, Y. A., Tsongidis, N. I., Karagiannakis, G., \& Konstandopoulos, A. G. (20I7). Multi-cyclic evaluation of composite $\mathrm{CaO}$-based structured bodies for thermochemical heat storage via the $\mathrm{CaO} / \mathrm{Ca}(\mathrm{OH}) 2$ reaction scheme. Solar Energy, 146, 65-78. https://doi.org/10.1016/j.solener.2017.02.013

Schaube, F., Koch, L., Wörner, A., \& Müller-Steinhagen, H. (20I2). A thermodynamic and kinetic study of the deand rehydration of $\mathrm{Ca}(\mathrm{OH}) 2$ at high $\mathrm{H} 2 \mathrm{O}$ partial pressures for thermo-chemical heat storage. Thermochimica Acta, 538, 9-20. https://doi.org/10.1016/j.tca.2012.03.003

Schaube, F., Utz, I., Wörner, A., \& Müller-Steinhagen, H. (20I3a). De- and rehydration of $\mathrm{Ca}(\mathrm{OH}) 2$ in a reactor with direct heat transfer for thermo-chemical heat storage. Part A: Experimental results. Chemical Engineering Research and Design, 91, 856-864. https://doi.org/10.1016/j.cherd.2012.09.020 
Schaube, F., Utz, l., Wörner, A., \& Müller-Steinhagen, H. (20I3b). De- and rehydration of $\mathrm{Ca}(\mathrm{OH}) 2$ in a reactor with direct heat transfer for thermo-chemical heat storage. Part B: Validation of model. Chemical Engineering Research and Design, 91, 865-873. https://doi.org//0.1016/j.cherd.2013.02.019

Schaube, F., Wörner, A., \& Tamme, R. (20I I). High temperature thermochemical heat storage for concentrated solar power using gas-solid reactions. Journal of Solar Energy Engineering, 133, 031006. https://doi.org//0.1115/1.4004245

Schmidt, M., Gutierrez, A., \& Linder, M. (2017). Thermochemical energy storage with $\mathrm{CaO} / \mathrm{Ca}(\mathrm{OH}) 2$ Experimental investigation of the thermal capability at low vapor pressures in a lab scale reactor. Applied Energy, 188, 672-681. https://doi.org/10.1016/j.apenergy.2016.11.023

Schmidt, M., \& Linder, M. (2017). Power generation based on the $\mathrm{Ca}(\mathrm{OH}) 2 / \mathrm{CaO}$ thermochemical storage system - Experimental investigation of discharge operation modes in lab scale and corresponding conceptual process design. Applied Energy, 203, 594-607. https://doi.org//0.1016/j.apenergy.2017.06.063

Sharma, R. K., Ganesan, P., Tyagi, V. V., Metselaar, H. S. C., \& Sandaran, S. C. (2015). Developments in organic solid-liquid phase change materials and their applications in thermal energy storage. Energy Conversion and Management, 95, 193-228. https://doi.org/10.1016/j.enconman.2015.01.084

Smolders, K., \& Baeyens, J. (2000). Cleaning of hot calciner exhaust gas by low-density ceramic filters. Powder Technology, II I (3), 240-244. https://doi.org// 0. I016/S0032-5910(99)0029I-0

Tescari, S., Singh, A., De Oliveira, L., Breuer, S., Agrafiotis, C., Roeb, M., Sattler, C., Marcher, J., Pagkoura, C., Karagiannakis, G., Konstandopoulos, A. G. (2017). Experimental proof of concept of a pilot-scale thermochemical storage unit. In AIP Conference Proceedings (Vol. 1850). American Institute of Physics Inc. https://doi.org//0.1063/I.4984455

Tescari, S., Singh, A., Agrafiotis, C., de Oliveira, L., Breuer, S., Schlögl-Knothe, B., Roeb, M., Sattler, C. (2017). Experimental evaluation of a pilot-scale thermochemical storage system for a concentrated solar power plant. Applied Energy, 189, 66-75. https://doi.org/10.1016/j.apenergy.2016.12.032

Tian, Y., \& Zhao, C. Y. (2013). A review of solar collectors and thermal energy storage in solar thermal applications. Applied Energy, 104, 538-553. https://doi.org/I0.1016/j.apenergy.2012.11.05I

Tiskatine, R., Aharoune, A., Bouirden, L., \& Ihlal, A. (2017). Identification of suitable storage materials for solar thermal power plant using selection methodology. Applied Thermal Engineering, 117, 591-608. https://doi.org/10.1016/j.applthermaleng.2017.01.107

Valverde, J. M., Barea-López, M., Perejón, A., Sánchez-Jiménez, P. E., \& Pérez-Maqueda, L. A. (2017). Effect of thermal pretreatment and nanosilica addition on limestone performance at calcium-looping conditions for thermochemical energy storage of concentrated solar power. Energy and Fuels, 31(4), 4226-4236. https://doi.org//0.102I/acs.energyfuels.6b03364

Wokon, M., Kohzer, A., \& Linder, M. (2017). Investigations on thermochemical energy storage based on technical grade manganese-iron oxide in a lab-scale packed bed reactor. Solar Energy, 153, 200-214. https://doi.org//0.1016/j.solener.2017.05.034

Xu, B., Li, P., \& Chan, C. (2015). Application of phase change materials for thermal energy storage in concentrated solar thermal power plants: A review to recent developments. Applied Energy, 160, 286-307. https://doi.org/10.1016/j.apenergy.2015.09.016

Yan, J., \& Zhao, C. Y. (2016). Experimental study of $\mathrm{CaO} / \mathrm{Ca}(\mathrm{OH}) 2$ in a fixed-bed reactor for thermochemical heat storage. Applied Energy, 175, 277-284. https://doi.org/10.1016/j.apenergy.2016.05.038

Yan, J., Zhao, C. Y., \& Pan, Z. H. (20I7). The effect of $\mathrm{CO} 2$ on $\mathrm{Ca}(\mathrm{OH}) 2$ and $\mathrm{Mg}(\mathrm{OH}) 2$ thermochemical heat storage systems. Energy, 124, II4-123. https://doi.org/10.1016/j.energy.2017.02.034 
Zhang, H. L., Baeyens, J., Degrève, J., Cáceres, G., Segal, R., \& Pitié, F. (20I4). Latent heat storage with tubularencapsulated phase change materials (PCMs). Energy, 76, 66-72. https://doi.org/10.1016/j.energy.2014.03.067

Zhang, H. L., Baeyens, J., Degrève, J., \& Cacères, G. (20I3). Concentrated solar power plants: Review and design methodology. Renewable and Sustainable Energy Reviews, 22, 466-48I. https://doi.org/10.1016/j.rser.2013.01.032

Zhang, H., Baeyens, J., Cáceres, G., Degrève, J., \& Lv, Y. (2016). Thermal energy storage: Recent developments and practical aspects. Progress in Energy and Combustion Science, 53, I-40. https://doi.org/10.1016/j.pecs.2015.10.003

Zhang, H., Benoit, H., Perez-Lopèz, I., Flamant, G., Tan, T., \& Baeyens, J. (2017). High-efficiency solar power towers using particle suspensions as heat carrier in the receiver and in the thermal energy storage. Renewable Energy, 111, 438-446. https://doi.org/10.1016/j.renene.2017.03.101

Zhang, H., Huys, K., Baeyens, J., Degrève, J., Kong, W., \& Lv, Y. (2016). Thermochemical energy storage for power generation on demand. Energy Technology, 4(2), 341-352. https://doi.org/10.1002/ente.201500261

Zhang, H., Kong, W., Tan, T., \& Baeyens, J. (2017b). High-efficiency concentrated solar power plants need appropriate materials for high-temperature heat capture, conveying and storage. Energy, 139, 52-64. https://doi.org/10.1016/j.energy.2017.07.129 